\title{
Finding key vulnerable areas by a climate change vulnerability assessment
}

\author{
Ho Gul Kim ${ }^{1}$ Dong Kun Lee ${ }^{1,2,3} \cdot$ Huicheul Jung ${ }^{4}$ Sung-Ho Kil ${ }^{5}$ • \\ Jin Han Park ${ }^{1}$ - Chan Park ${ }^{6}$ - Riwako Tanaka ${ }^{2}$ Changwan Seo ${ }^{7}$. \\ Ho $\mathrm{Kim}^{8}$ - Wooseok Kong ${ }^{9}$ Kyusik $\mathrm{Oh}^{10}$ - Jinyong Choi ${ }^{2}$. \\ Young-Ju Oh ${ }^{11}$ - Gangseok Hwang ${ }^{12}$ Chang-Keun Song ${ }^{13}$
}

Received: 27 November 2014/ Accepted: 1 January 2016/Published online: 22 January 2016

(C) The Author(s) 2016. This article is published with open access at Springerlink.com

\begin{abstract}
Extreme climate events such as typhoons, heat waves, and floods have increased in frequency with climate change. Many municipalities within the Republic of Korea (ROK) have experienced damage from these events, necessitating countermeasures. Vulnerability assessment has been suggested in the implementation of a national plan for reducing damage resulting from climate change. Thus, in this study, we assess the vulnerability of the ROK and identify key vulnerable municipalities in support of the national adaptation plan. We create a framework for assessing the vulnerability of all 232
\end{abstract}

\section{Dong Kun Lee}

dklee7@snu.ac.kr

1 Interdisciplinary Program in Landscape Architecture, Seoul National University, \#200, College Agricultural Life Science, Daehak-dong, Gwanak-gu, Seoul, Republic of Korea

2 Department of Landscape Architecture and Rural System Engineering, Seoul National University, Seoul, Republic of Korea

3 Research Institute of Agriculture and Life Sciences, Seoul National University, Seoul, Republic of Korea

4 Korea Environment Institute, Seoul, Republic of Korea

5 Department of Landscape Architecture and Urban Planning, Texas A\&M University, College Station, TX, USA

6 Korea Research Institute for Human Settlements, Anyang, Republic of Korea

7 National Institute of Ecology, Seocheon-gun, Republic of Korea

8 Graduate School of Public Health, Seoul National University, Seoul, Republic of Korea

9 Department of Geography, Kyung Hee University, Seoul, Republic of Korea

10 Department of Urban Engineering, Hanyang University, Seoul, Republic of Korea

11 Korea Biodiversity Research Center Co., Ltd, Pocheon, Republic of Korea

12 National Fisheries Research and Development Institute, Busan, Republic of Korea

13 Air Quality Forecasting Center, National Institute of Environmental Research, Incheon, Republic of Korea 
municipalities of the ROK with respect to 32 items in 7 fields. The framework regards decision makers' comprehension and availability of data as important factors. We assess the vulnerability index of each municipality by using variables of climate exposure, sensitivity, and adaptation capacity. The weights of variables are determined by the Delphi method. We used the representative concentration pathways 8.5 climate scenario to reflect future climate exposure for the vulnerability assessment. From the analysis, vulnerability maps are prepared for the 32 items of 7 fields, and key vulnerable municipalities are identified by aggregating the maps. The distribution of vulnerable municipalities changes with the future climate conditions. These maps provide a scientific and objective basis for the ROK government to establish adaptation plans and allocate resources. The ROK government can utilize the results to identify the characteristics of highly vulnerable areas, and municipalities can use the results as a basis for requesting support from the national government.

Keywords Mapping vulnerability - National climate change adaptation strategies · Resource allocation $\cdot$ RCP scenario

\section{Introduction}

Development activities of humankind have emitted a significant quantity of greenhouse gases to cause climate change (Moreno and Becken 2009; European Environment Agency 2012), which in turn causes negative or positive effects in various fields on a global scale (IPCC 2012). These effects simultaneously encompass short-term effects including extreme weather such as typhoons, heavy rainfall, heat waves, and cold waves and longterm effects such as gradual increases or decreases in the temperature and rainfall (e.g., Arnell et al. 2005; Wang et al. 2013; Mikami et al. 2014; Silva and Pereira 2014). Thus, the assessment and solution of problems caused by climate change affecting a large area require the consideration of a variety of human activity sectors and environmental characteristics, expressed by means of very diverse variables.

The Intergovernmental Panel on Climate Change (IPCC 2012), a representative community focusing on research relevant to climate change, separated this research theme into three working groups. Group I assesses the climate system and climate change; group II assesses the vulnerability of systems and adaptation options to reduce damages; and group III assesses mitigation options related to preventing greenhouse gas emissions (Lee et al. 2013). The present study focuses on the work of group II in assessing vulnerabilities, predicting negative effects, and supporting adaptation options to reduce damage. Many researchers have attempted to assess the impacts and vulnerability to climate change (Füssel and Klein 2006; Fekete 2012; Varazanashvili et al. 2012; Siagian et al. 2014). Moreover, many studies have determined that diverse events are related to climate change and have demanded proper adaptation plans for counteracting its effects.

Such studies have focused mainly on specific items or fields of certain areas. For example, studies on landslide risk have focused only on the identification of landslide hazard area without interest in other items or fields (Al-Adamat et al. 2003; Allison et al. 2009; Moreno and Becken 2009; Camarasa Belmonte et al. 2011; Antwi-Agyei et al. 2012; Eckert et al. 2012; Houghton et al. 2012; Menoni et al. 2012). Although such research can help to improve existing methodologies and supports municipalities within the study area, 
the government cannot utilize the results to prepare national adaptation plans and options. This is an issue because climate change affects large areas rather than only small or local areas. Therefore, the entire extent of the Republic of Korea (ROK) and various fields should be assessed to support a national adaptation plan.

The objectives of this study are to determine methods for assessing the vulnerability of various fields and areas by using a single framework and to identify their mechanisms. Moreover, this study identifies municipalities with most urgent areas in which to establish adaptation plans and attempts to develop a framework for assessing various fields in many municipalities. The framework is developed to incorporate a combination of quantitative and qualitative methods for improving the comprehension and availability of data of decision makers and considers limitations of time, cost, and data. The properties of the vulnerability fields are analyzed by checking variables. This study identifies key vulnerable areas to support the establishment of a national adaptation plan. The developed framework and method for finding these such areas can also serve as an effective tool for use by governments of other countries.

\section{Methods}

\subsection{Scope of study}

This study comprises two parts (Fig. 1): vulnerability assessment and the identification of key vulnerable areas. The first part focuses on the selection of fields and items, establishment of data, and assessment of vulnerability. The second part concentrates on classifying vulnerability grades, creating first-grade and key vulnerability maps, and analyzing the characteristics of key vulnerable municipalities.

The study area is the ROK, which consists of 232 municipalities. The municipalities are used as spatial units for vulnerability assessment because each spatial unit is appropriate for formulating and implementing policies (Allison et al. 2009). Additionally, each municipality of the ROK must establish its own climate adaptation plan according to the basic act on low-carbon green growth. Seven fields are considered, including health, forests, water management, ecosystem, agriculture, fisheries, and disasters, which consist of 32 specific items. The fields and items were selected on the basis of climate change adaptation strategies of the ROK.

The temporal scope was established to include the present (2001-2010) and future (2046-2055) years. In the national adaptation strategy, the ROK government set 2050 as the long-term target year for adaptation. This study considers only the change in climate conditions to identify its effects, as there are not enough data to estimate the future condition of the ROK. In addition, the government of ROK determined that future data have considerable uncertainty.

The variables for sensitivity and adaptive capacity were selected by reviewing previous studies provided by national institutes of various fields. Climate exposure variables were provided by the Korea Meteorological Administration (KMA). The representative concentration pathways (RCP) 8.5 climate change scenario was applied to establish future climate data. This scenario, known as the business-as-usual (BAU) scenario, is the worst of RCP scenarios and assumes that insufficient effort is put forth in reducing greenhouse gas emissions. The KMA used the HadGEM3-RA model to produce the RCP 8.5 scenario data. An average of 10 years of climate data pertaining to climatic prediction was used in the assessment for anticipating future conditions. 


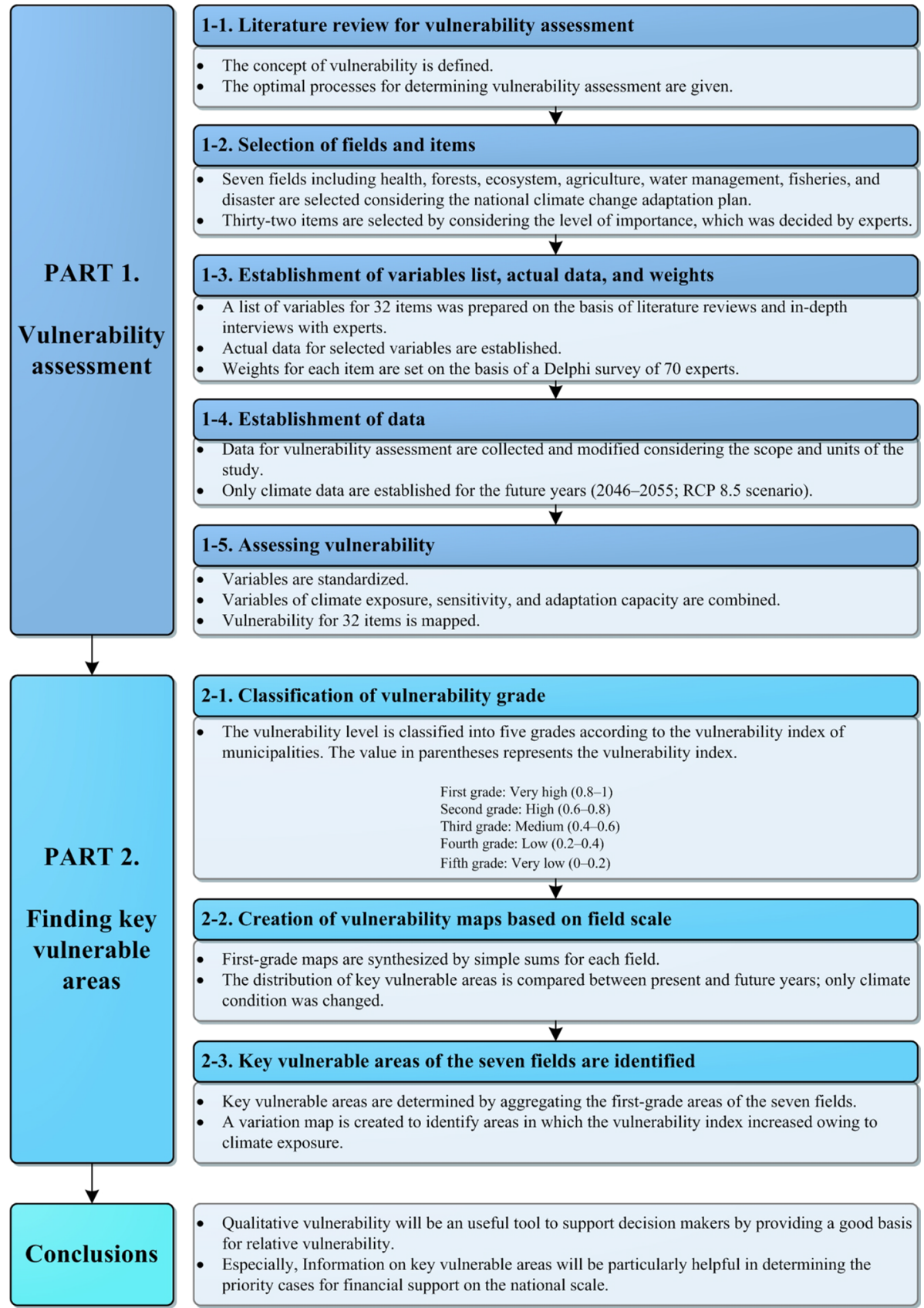

Fig. 1 Flowchart of this study 


\subsection{Methods of vulnerability assessment}

Vulnerability is the degree to which a system is susceptible to negative effects of climate change, such as climate variation and extreme weather (White et al. 2001). Vulnerability is defined as a function of climate exposure, sensitivity, and adaptive capacity based on the assessment of the magnitude of climate change and variations (Schneider et al. 2007). Climate exposure is the degree to which a system is exposed to significant climatic variations that can cause damage. Sensitivity is the degree to which a system is affected, either negatively or positively, by climate-related stimulation. The adaptive capacity is the ability of a system to adjust to climate change variability and extreme weather, to reduce potential damage, or to address the results (White et al. 2001; Füssel and Klein 2006; Allison et al. 2009).

The process of this study is detailed in Fig. 1. The seven fields selected are the same as those used by the government in the national climate change adaptation strategy. Thirtytwo items for the seven fields were selected considering experts' opinions and important issues of the ROK. Representative variables were then selected for the items of each field. Three characteristics were considered for the seven fields, each of which was assessed by using a series of variables.

Variables for the vulnerability assessment were selected on the basis of article reviews and in-depth interviews with experts. The 32 items were assessed by using categories of climate exposure, sensitivity, and adaptation capacity, and each category included four to six variables. Thus, the theoretical number of variables was greater than 360 . However, because duplicate variables were applied to various fields and items in some cases, the actual number of variables was approximately 200. The selected variables were improved and verified by consultation with the climate change consulting group of the Korea Environment Institute, which consists of experts in climate change impacts and adaptation in various fields (Table 1).

After selection of the variables, their weights were developed to determine the contribution of each. Because it was difficult to set weights on the basis of the literature reviews and interviews, the Delphi method was used to reach a consensus value from a large number of experts by synthesizing their subjective value and using a feedback process.

Seventy experts were selected for application of the Delphi method for the seven fields. The experts consisted of professors and researchers who performed research relevant to climate change. The execution of the Delphi method required three months, from July to September 2011. The weights were surveyed twice to reach agreement. Each expert set weights by comparing his or her own weights with the average weights of the other experts. Two types of weights were identified in the vulnerability assessment (Table 2). The first weights (FW) were set for climate change (FWce), sensitivity (FWs), and adaptation capacity (FWac), and the sum of the first weights was set as one. The second weights (SW) were set for specific variables in the three categories. The sum of the second weights for climate exposure, sensitivity, and adaptation capacity was also set as one.

Data were established for assessment after variable selection and weight setting. Climate data for the present years (2001-2010) and future years (2046-2055; RCP 8.5) were obtained from the KMA. The climate data were converted to various types, considering the properties of the field, such that shown in Table 3. For sensitivity, the sources of data varied because the properties differ among fields and items. Data for the forest and ecosystem fields were collected from the Korea Forest Service, the Korea Environment 
Table 1 List of items considered for vulnerability assessment

\begin{tabular}{|c|c|c|c|}
\hline No. & Field & No. & Item \\
\hline \multirow[t]{9}{*}{1} & \multirow[t]{9}{*}{ Health } & 1 & Health vulnerability due to floods \\
\hline & & 2 & Health vulnerability due to typhoons \\
\hline & & 3 & Health vulnerability due to heat waves \\
\hline & & 4 & Health vulnerability due to cold waves \\
\hline & & 5 & Health vulnerability due to ozone enhancement \\
\hline & & 6 & Health vulnerability due to fine dust \\
\hline & & 7 & Health vulnerability due to air pollutants \\
\hline & & 8 & Health vulnerability due to infectious diseases \\
\hline & & 9 & Health vulnerability by waterborne epidemics \\
\hline \multirow[t]{7}{*}{2} & \multirow[t]{7}{*}{ Forests } & 10 & Landslides due to heavy rainfall \\
\hline & & 11 & Vulnerability of trails due to landslides \\
\hline & & 12 & Vulnerability to forest fire \\
\hline & & 13 & Vulnerability of pine trees to disease and pests \\
\hline & & 14 & Vulnerability of pine trees to pine fungi \\
\hline & & 15 & Vulnerability of forest productivity \\
\hline & & 16 & Vulnerability of vegetation due to drought \\
\hline \multirow[t]{3}{*}{3} & \multirow[t]{3}{*}{ Ecosystem } & 17 & Vulnerability of vegetation growth \\
\hline & & 18 & Vulnerability of insects \\
\hline & & 19 & Vulnerability of management of protected areas \\
\hline \multirow[t]{5}{*}{4} & \multirow[t]{5}{*}{ Agriculture } & 20 & Vulnerability of farmlands to erosion \\
\hline & & 21 & Vulnerability of cultivation facility \\
\hline & & 22 & Vulnerability of productivity of rice crops \\
\hline & & 23 & Vulnerability of productivity of apple crops \\
\hline & & 24 & Vulnerability of productivity of livestock \\
\hline \multirow[t]{3}{*}{5} & \multirow[t]{3}{*}{ Water management } & 25 & Vulnerability of flood regulation \\
\hline & & 26 & Vulnerability of water utilization \\
\hline & & 27 & Vulnerability of water quality \\
\hline 6 & Fisheries & 28 & Vulnerability of fisheries due to change in water temperature \\
\hline \multirow[t]{4}{*}{7} & \multirow[t]{4}{*}{ Disaster } & 29 & Vulnerability of infrastructure to floods \\
\hline & & 30 & Vulnerability of infrastructure to heat waves \\
\hline & & 31 & Vulnerability of infrastructure to heavy snow \\
\hline & & 32 & Vulnerability of infrastructure to sea level increase \\
\hline
\end{tabular}

Institute, and the Ministry of Environment. Data on the water management and disaster fields were provided by the Korea Water Resources Corporation and Korea Ministry of Land, Infrastructure, and Transport. Data relevant to the health field were established by using data from the Korea Ministry of Health and Welfare and the National Health Insurance Service. Information on the agriculture field was constructed by using data from the Korea Rural Community Corporation. Fishery field data were obtained from the Korea Ministry of Oceans and Fisheries. Data for adaptation capacity were provided by the National Statistical Office.

The vulnerability assessment processes included several variables, each with different scales. The objective of the vulnerability assessment was to compare relative 
Table 2 Method of setting weights

\begin{tabular}{|c|c|c|c|c|c|c|}
\hline Item & Variable & $\begin{array}{l}\text { First } \\
\text { weights }\end{array}$ & $\begin{array}{l}\text { Sum of } \\
\text { weights }\end{array}$ & $\begin{array}{l}\text { Specific } \\
\text { variable }\end{array}$ & $\begin{array}{l}\text { Second } \\
\text { weights }\end{array}$ & $\begin{array}{l}\text { Sum of } \\
\text { weights }\end{array}$ \\
\hline \multirow[t]{12}{*}{ Item A } & \multirow[t]{4}{*}{ Climate exposure } & \multirow[t]{4}{*}{ FWce } & \multirow[t]{12}{*}{1} & Variable a & SWa & \multirow[t]{4}{*}{1} \\
\hline & & & & Variable b & $\mathrm{SWb}$ & \\
\hline & & & & Variable c & SWc & \\
\hline & & & & Variable d & SWd & \\
\hline & \multirow[t]{4}{*}{ Sensitivity } & \multirow[t]{4}{*}{ FWs } & & Variable e & SWe & \multirow[t]{4}{*}{1} \\
\hline & & & & Variable f & SWf & \\
\hline & & & & Variable $\mathrm{g}$ & $\mathrm{SWg}$ & \\
\hline & & & & Variable $\mathrm{h}$ & SWh & \\
\hline & \multirow[t]{4}{*}{ Adaptation capacity } & \multirow[t]{4}{*}{ FWac } & & Variable i & SWi & \multirow[t]{4}{*}{1} \\
\hline & & & & Variable j & $\mathrm{SWj}$ & \\
\hline & & & & Variable k & SWk & \\
\hline & & & & Variable 1 & SWl & \\
\hline
\end{tabular}

Table 3 Variables and weights for landslide vulnerability due to heavy rainfall

\begin{tabular}{|c|c|c|c|c|}
\hline Item & Variable & $\begin{array}{l}\text { First } \\
\text { Weight }\end{array}$ & Specific variable & $\begin{array}{l}\text { Second } \\
\text { weight }\end{array}$ \\
\hline \multirow{12}{*}{$\begin{array}{l}\text { Landslide due } \\
\text { to } \\
\text { heavy } \\
\text { rainfall }\end{array}$} & \multirow[t]{4}{*}{$\begin{array}{l}\text { Climate } \\
\text { exposure }\end{array}$} & \multirow[t]{4}{*}{0.40} & $\begin{array}{l}\text { Number of dates with more than } 80 \mathrm{~mm} \text { of } \\
\text { precipitation }\end{array}$ & 0.24 \\
\hline & & & Daily maximum precipitation (mm) & 0.39 \\
\hline & & & Summer daily precipitation (mm) & 0.21 \\
\hline & & & Five days of maximum precipitation (mm) & 0.16 \\
\hline & \multirow[t]{4}{*}{ Sensitivity } & \multirow[t]{4}{*}{0.37} & Average slope of regional forest $\left(^{\circ}\right)$ & 0.35 \\
\hline & & & Area of coniferous forest (ha) & 0.24 \\
\hline & & & Average height of regional forest (m) & 0.12 \\
\hline & & & Denuded area (ha) & 0.29 \\
\hline & \multirow{4}{*}{$\begin{array}{l}\text { Adaptation } \\
\text { capacity }\end{array}$} & \multirow[t]{4}{*}{0.23} & Government officials per population & 0.20 \\
\hline & & & Area of preventing forest destruction (ha) & 0.24 \\
\hline & & & GRDP (trillion won) & 0.18 \\
\hline & & & Financial independence $(\%)$ & 0.38 \\
\hline
\end{tabular}

vulnerabilities. Therefore, this study normalized all of the variables to make the vulnerability indices comparable. The selected variables were standardized by

$$
Z_{i, j}=\frac{X_{i, j}-X_{i}^{\mathrm{MIN}}}{X_{i}^{\mathrm{MAX}}-X_{i}^{\mathrm{MIN}}},
$$

where $Z_{i, j}$ is the standardized value of the variable $i$ (climate exposure, sensitivity, or adaptation capacity) of item $j ; X_{i, j}$ is the unstandardized value of variable $i$ of item $j ; X_{i}^{\mathrm{MAX}}$ is the maximum value of the variable for item $j$; and $X_{i}^{\mathrm{MIN}}$ is the minimum value of the variable for item $j$. The scale of the variables was normalized from 0 to 1 by Eq. (1). In addition, the vulnerability indices were normalized considering the vulnerability values of 
present and future years according to climate change scenarios. A similar standardization method was used for the Human Development Index (McGillivray and White 1993; Noorbakhsh 1998).

Numerous methods use climate exposure (CE), sensitivity $(S)$, and adaptation capacity (AC) to assess vulnerability, which may differ according to the scale of analysis, property of field, and availability of data (Turner et al. 2003; Sullivan and Meigh 2007). This study used Eqs. (2) and (3) for assessing vulnerability (Adger and Vincent 2005; Allison et al. 2009). In Eq. (2), FWce, FWs, and FWac are the first weights for the variables, and $\mathrm{CE}_{n}, S_{n}$, and $\mathrm{AC}_{n}$ are the normalized CE, S, and $\mathrm{AC}$. In Eq. (3), SW is the second weight for each variable, and the variable is normalized from 0 to 1 .

$$
\begin{aligned}
& V=\mathrm{FWce} \times \mathrm{CE}_{n}+\mathrm{FW}_{n} \times S_{n}-\mathrm{FWac} \times \mathrm{AC}_{n} \\
& \mathrm{CE}=\sum\left(\mathrm{SW}_{i} \times \text { Variable }_{i}\right) \\
& S=\sum\left(\mathrm{SW}_{i} \times \text { Variable }_{i}\right) \\
& \mathrm{AC}=\sum\left(\mathrm{SW}_{i} \times \text { Variable }_{i}\right)
\end{aligned}
$$

The first and second weights were applied to the equations to reflect the relative importance of the variables. This simple equation has advantages for clarifying the impacts of the weights and facilitating the understanding of decision makers. Additionally, municipalities can easily adjust the equation when more detailed data are needed for vulnerability assessment.

The most vulnerable case has the highest value in the equations and the lowest possible level of adaptation capacity; the least vulnerable cases have the lowest value. The highest and lowest values differed among items. However, because this study focused only on relative levels of vulnerability, such differences did not affect the results. In addition, operators should be aware that although the vulnerability index is expressed as a quantitative value, it has a qualitative meaning according to the properties of the vulnerability assessment.

\subsection{Methods of identifying key vulnerable areas}

The objective of the second part is this study was to create key vulnerability maps for identifying highly vulnerable municipalities and analyzing their properties. The vulnerability level was classified into five grades according to the vulnerability index of municipalities. The first grade, which represents the highest vulnerability, had a normalized vulnerability value of $0.8-1$ (Fig. 1).

After classification of the vulnerability grades, the first-grade maps were synthesized on the basis of each field. This was done for two reasons. The first is that the government considers fields and municipalities when allocating financial resources, and the second is that it is difficult to show every map in this study owing to space limitations. Synthesized maps were made for the seven fields. Future maps considered only the changes in climate exposure to determine the effects of climate change. As previously stated, sensitivity and adaptation capacity data were not available for future conditions, and the existing data were not evaluated because of their large uncertainties.

The key vulnerability map was created by synthesizing the seven first-grade maps for each field; thus, the map included the first-grade areas of 32 items. The 232 
municipalities were classified into five grades, considering the number of the first grade of each item. The first grade of the key vulnerability map included the most vulnerable areas, and the fifth grade included the least vulnerable areas. The key vulnerability map was created to describe the most vulnerable areas, considering whole fields in the ROK. Therefore, this map could be utilized as an important basis for the allocation of financial resources.

\section{Results and discussion}

\subsection{Vulnerability assessment for representative item}

The results were too numerous to include comprehensively in this paper. Therefore, a representative item, "landslides due to heavy rainfall," in the forest field was selected to show a specific result of the vulnerability assessment. Table 3 shows the variables and weights of the landslide item. Information on the variables and weights for the other 31 items is included in Appendix. Each of the three variables-climate exposure, sensitivity, and adaptation capacity — consists of four specific variables (Table 3). A map of each of the three main variables was created by multiplying the standardized variables and weights. The vulnerability map was derived from the three maps by using Eqs. (2) and (3).

Figure 2 shows the result of the vulnerability assessment for landslides due to heavy rainfall in the present years (2000-2010). Four maps, each for climate exposure, sensitivity, adaptation capacity, and vulnerability, included approximately 232 municipalities. The map legends are classified into five grades to show the relative levels of vulnerability. The highest grade includes municipalities with values of $0.8-1$; the lowest grade includes those with values of $0-0.2$. The five grades were categorized as highest, high, medium, low, and lowest in reference to a previous study (o'Brien et al. 2004).

The climate exposure map was derived by using four specific variables and the weights of each variable (Table 2). Daily maximum precipitation had the highest weight among the variables; therefore, the distribution of the climate exposure map is strongly affected by the daily maximum precipitation. The northwestern and southeastern regions of the ROK showed high climate exposure (Kil et al. 2015).

The sensitivity map also considered four specific variables and weights (Table 3); the slope of the forests, area covered by coniferous trees, and denuded area were important standards for assessing the sensitivity. The sensitivity was affected by the area of forests in municipalities because most of the variables are related to forests. In particular, the eastern region of the ROK is steeper and has higher altitudes than the western region. Thus, the western region showed a high sensitivity value on the map.

The adaptation capacity map was calculated by using four specific variables and their weights (Table 3). The variables were focused on the ability of municipalities to address landslides. Financial independence and areas resistant to forest destruction were important variables in reacting to landslides. Moreover, the adaptation capacity was higher in the northwestern and southeastern regions than those in other areas.

The vulnerability map was derived from climate exposure, sensitivity, and adaptation capacity (Eq. 2). Vulnerable areas had high climate exposure, high sensitivity, and low adaptation capacity. Therefore, areas with high adaptation capacity could still have low 

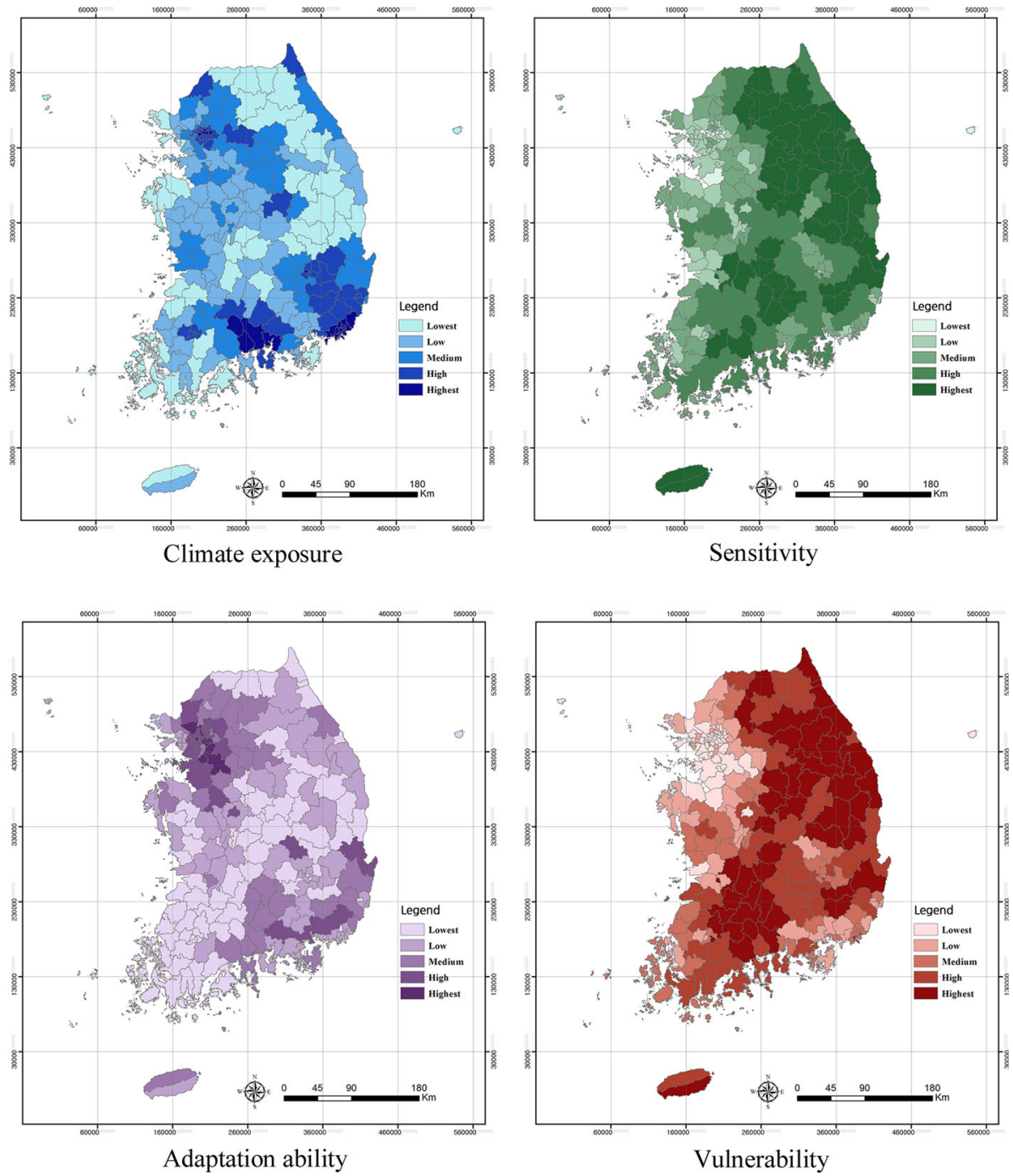

Fig. 2 Maps of vulnerability to landslides due to heavy rainfall

vulnerability (o'Brien et al. 2004). In the vulnerability map, the northwestern and southeastern regions showed low vulnerability because they had a high adaptation capacity.

\subsection{Validation for representative item}

The validation process was conducted for the vulnerability of landslides due to heavy rainfall by comparing the vulnerability index with records of past landslide occurrences. The records contain landslide occurrence areas and the number of landslide occurrences in the 232 municipalities for the years 2001-2010. Table 4 shows an example of 2006 landslide occurrence data for the representative province, Gangwon-do, which includes 18 
Table 4 Example of landslide occurrence records and vulnerability index

\begin{tabular}{lllrl}
\hline Province & Name of municipality & $\begin{array}{l}\text { Area of landslide (ha) } \\
\text { (Temporal scope: 2006) }\end{array}$ & $\begin{array}{c}\text { Number of } \\
\text { occurrences }\end{array}$ & $\begin{array}{l}\text { Vulnerability } \\
\text { index }\end{array}$ \\
\hline \multirow{2}{*}{ Gangwon-do } & Chuncheon-si & 9.88 & 148 & 0.80 \\
& Wonju-gun & 2.60 & 15 & 0.72 \\
& Gangneung-gun & 7.20 & 116 & 0.77 \\
& Donghae-si & 0 & 0 & 0.72 \\
Taebaek-si & 1.80 & 12 & 0.68 \\
Sokcho-si & 0 & 0 & 0.63 \\
Samcheok-si & 2.50 & 11 & 0.73 \\
Hongcheon-gun & 11.00 & 137 & 0.76 \\
& Hoengseong-gun & 27.44 & 205 & 0.82 \\
Yeongwol-gun & 3.80 & 57 & 0.80 \\
Pyeongchang-gun & 279.41 & 2269 & 0.83 \\
Jeongseon-gun & 7.3 & 93 & 0.74 \\
Cheorwon-gun & 0 & 0 & 0.59 \\
Hwacheon-gun & 2.00 & 50 & 0.67 \\
Yanggu-gun & 24.66 & 224 & 0.81 \\
Inje-gun & 106.20 & 801 & 0.81 \\
Goseong-gun & 0 & 0 & 0.61 \\
Yangyang-gun & 3.70 & 79 & 0.78 \\
\hline
\end{tabular}

Source: Gangwon-do, 2006

municipalities, and $81.7 \%$ forestland. These characteristics indicate that Gangwon-do is highly vulnerable to landslides.

The Pearson correlation analysis for the 232 municipalities revealed a correlation coefficient for the vulnerability index and landslide occurrence areas (ha) of 0.594, significant at the 0.01 level according to the two-tailed test. The correlation coefficient of the vulnerability index and landslide number (counts) was 0.457 , significant at the 0.05 level also according to the two-tailed test. The vulnerability index for landslides was considered to be reliable based on a high correlation with independent data. Landslide occurrence data for other areas was not available for security reasons.

This study also conducted Pearson correlation analysis as validation for other items using independent data, including the frequency of events, damage from events, and monitoring information. In addition, correlation of vulnerability indices and independent data was made by Pearson analysis. The correlation coefficient and significance were checked to assess the reliability of the vulnerability indices. Every item showed reliable results upon conducting a feedback process considering the correlation coefficient with independent data.

The results and data related to validation were too lengthy to include in this paper. Thus, to provide detailed information, Table 5 shows the data type and source for validation. Each field required various data types for validation of the vulnerability index. In many cases, alternative data were used because it was difficult to find optimal data for all items. For example, the water management field compared the vulnerability of the water quality with the budget of purifying the contaminated water in each municipality. 
Table 5 Validation data for vulnerability items

\begin{tabular}{|c|c|c|c|c|}
\hline Fields & No. & Item & Data type for validation (unit) & Source of data \\
\hline \multirow[t]{9}{*}{ Health } & 1 & $\begin{array}{l}\text { Health } \\
\text { vulnerability } \\
\text { due to floods }\end{array}$ & $\begin{array}{l}\text { Mortality rates due to floods, } \\
\text { morbidity of waterborne } \\
\text { epidemics (ratio) }\end{array}$ & $\begin{array}{l}\text { National Emergency } \\
\text { Management Agency, } \\
\text { Ministry of Health and } \\
\text { Welfare }\end{array}$ \\
\hline & 2 & $\begin{array}{l}\text { Health } \\
\text { vulnerability } \\
\text { due to typhoons }\end{array}$ & $\begin{array}{l}\text { Mortality rates due to typhoons } \\
\text { (ratio) }\end{array}$ & $\begin{array}{l}\text { National Emergency } \\
\text { Management Agency, } \\
\text { Ministry of Health and } \\
\text { Welfare }\end{array}$ \\
\hline & 3 & $\begin{array}{l}\text { Health } \\
\text { vulnerability } \\
\text { due to heat } \\
\text { waves }\end{array}$ & $\begin{array}{l}\text { Mortality rates due to heat waves, } \\
\text { records of emergency room visits } \\
\text { during heat waves (ratio) }\end{array}$ & $\begin{array}{l}\text { Ministry of Health and Welfare, } \\
\text { National Emergency } \\
\text { Department Information } \\
\text { System }\end{array}$ \\
\hline & 4 & $\begin{array}{l}\text { Health } \\
\text { vulnerability } \\
\text { due to cold } \\
\text { waves }\end{array}$ & $\begin{array}{l}\text { Mortality rates due to cold waves, } \\
\text { records of emergency room visits } \\
\text { during cold waves (ratio) }\end{array}$ & $\begin{array}{l}\text { Ministry of Health and Welfare, } \\
\text { National Emergency } \\
\text { Department Information } \\
\text { System }\end{array}$ \\
\hline & 5 & $\begin{array}{l}\text { Health } \\
\text { vulnerability } \\
\text { due to ozone } \\
\text { enhancement }\end{array}$ & $\begin{array}{l}\text { Records of emergency room visits } \\
\text { during ozone warning (ratio) }\end{array}$ & $\begin{array}{l}\text { Ministry of Health and Welfare, } \\
\text { National Emergency } \\
\text { Department Information } \\
\text { System }\end{array}$ \\
\hline & 6 & $\begin{array}{l}\text { Health } \\
\text { vulnerability } \\
\text { due to fine dust }\end{array}$ & $\begin{array}{l}\text { Morbidity of lung disease and } \\
\text { respiratory disease (ratio) }\end{array}$ & Ministry of Health and Welfare \\
\hline & 7 & $\begin{array}{l}\text { Health } \\
\text { vulnerability } \\
\text { due to air } \\
\text { pollutants }\end{array}$ & $\begin{array}{l}\text { Morbidity of lung disease and } \\
\text { respiratory disease, records of } \\
\text { allergy patients (ratio) }\end{array}$ & Ministry of Health and Welfare \\
\hline & 8 & $\begin{array}{l}\text { Health } \\
\text { vulnerability } \\
\text { due to } \\
\text { infectious } \\
\text { diseases }\end{array}$ & $\begin{array}{l}\text { Morbidity of infectious diseases } \\
\text { (ratio) }\end{array}$ & $\begin{array}{l}\text { Ministry of Health and Welfare, } \\
\text { National Health Insurance } \\
\text { Corporation }\end{array}$ \\
\hline & 9 & $\begin{array}{l}\text { Health } \\
\text { vulnerability by } \\
\text { waterborne } \\
\text { epidemics }\end{array}$ & $\begin{array}{l}\text { Morbidity of waterborne epidemics } \\
\text { (ratio) }\end{array}$ & $\begin{array}{l}\text { Ministry of Health and Welfare, } \\
\text { National Health Insurance } \\
\text { Corporation }\end{array}$ \\
\hline \multirow[t]{4}{*}{ Forests } & 10 & $\begin{array}{l}\text { Landslides due to } \\
\text { heavy rainfall }\end{array}$ & $\begin{array}{l}\text { Landslide occurrence records (area, } \\
\text { number) }\end{array}$ & $\begin{array}{l}\text { Korea Forest Service, National } \\
\text { Emergency Management } \\
\text { Agency }\end{array}$ \\
\hline & 11 & $\begin{array}{l}\text { Vulnerability of } \\
\text { trails due to } \\
\text { landslides }\end{array}$ & $\begin{array}{l}\text { Landslide occurrence records, } \\
\text { restoration records for forest trails } \\
\text { (area) }\end{array}$ & $\begin{array}{l}\text { Korea Forest Service, Korea } \\
\text { National Park Service }\end{array}$ \\
\hline & 12 & $\begin{array}{l}\text { Vulnerability to } \\
\text { forest fire }\end{array}$ & Forest fire records (area, number) & $\begin{array}{l}\text { Korea Forest Service, National } \\
\text { Emergency Management } \\
\text { Agency }\end{array}$ \\
\hline & 13 & $\begin{array}{l}\text { Vulnerability of } \\
\text { pine trees to } \\
\text { disease and } \\
\text { pests }\end{array}$ & $\begin{array}{l}\text { Records of disease and pests in pine } \\
\text { trees (area) }\end{array}$ & $\begin{array}{l}\text { Korea Forest Service, Korea } \\
\text { National Park Service }\end{array}$ \\
\hline
\end{tabular}


Table 5 continued

\begin{tabular}{|c|c|c|c|c|}
\hline Fields & No. & Item & Data type for validation (unit) & Source of data \\
\hline & 14 & $\begin{array}{l}\text { Vulnerability of } \\
\text { pine trees to } \\
\text { pine fungi }\end{array}$ & $\begin{array}{l}\text { Records of damage due to pine fungi } \\
\text { (area) }\end{array}$ & $\begin{array}{l}\text { Korea Forest Service, } \\
\text { Korea National Park } \\
\text { Service }\end{array}$ \\
\hline & 15 & $\begin{array}{l}\text { Vulnerability of } \\
\text { forest } \\
\text { productivity }\end{array}$ & $\begin{array}{l}\text { Gross primary production, net } \\
\text { primary production data (number) }\end{array}$ & $\begin{array}{l}\text { Korea Forest Service, } \\
\text { Korea Forest Research } \\
\text { Institute }\end{array}$ \\
\hline & 16 & $\begin{array}{l}\text { Vulnerability of } \\
\text { vegetation due } \\
\text { to drought }\end{array}$ & $\begin{array}{l}\text { Records of dead trees due to drought } \\
\text { (number) }\end{array}$ & Korea Forest Service \\
\hline \multirow[t]{3}{*}{ Ecosystem } & 17 & $\begin{array}{l}\text { Vulnerability of } \\
\text { vegetation } \\
\text { growth }\end{array}$ & $\begin{array}{l}\text { Age class of vegetation, gross } \\
\text { primary production, net primary } \\
\text { production data (number) }\end{array}$ & $\begin{array}{l}\text { Korea Forest Service, } \\
\text { Korea Forest Research } \\
\text { Institute }\end{array}$ \\
\hline & 18 & $\begin{array}{l}\text { Vulnerability of } \\
\text { insects }\end{array}$ & $\begin{array}{l}\text { Records of damage to trees due to } \\
\text { insects (area) }\end{array}$ & $\begin{array}{l}\text { Korea Forest Service, } \\
\text { Korea Forest Research } \\
\text { Institute, Korea } \\
\text { National Park Service }\end{array}$ \\
\hline & 19 & $\begin{array}{l}\text { Vulnerability of } \\
\text { management } \\
\text { of protected } \\
\text { areas }\end{array}$ & $\begin{array}{l}\text { Damage of protected areas due to } \\
\text { extreme weather (cost) }\end{array}$ & $\begin{array}{l}\text { Korea National Park } \\
\text { Service, Ministry of } \\
\text { Environment }\end{array}$ \\
\hline \multirow[t]{5}{*}{ Agriculture } & 20 & $\begin{array}{l}\text { Vulnerability of } \\
\text { farmlands to } \\
\text { erosion }\end{array}$ & $\begin{array}{l}\text { Damage of farmlands due to erosion } \\
\text { (area) }\end{array}$ & $\begin{array}{l}\text { Ministry of Agriculture, } \\
\text { Food and Rural Affairs }\end{array}$ \\
\hline & 21 & $\begin{array}{l}\text { Vulnerability of } \\
\text { cultivation } \\
\text { facility }\end{array}$ & $\begin{array}{l}\text { Damage of cultivation facility due to } \\
\text { extreme weather (cost) }\end{array}$ & $\begin{array}{l}\text { Ministry of Agriculture, } \\
\text { Food and Rural Affairs, } \\
\text { National Emergency } \\
\text { Management Agency }\end{array}$ \\
\hline & 22 & $\begin{array}{l}\text { Vulnerability of } \\
\text { productivity of } \\
\text { rice crop }\end{array}$ & $\begin{array}{l}\text { Decrease in rice productivity due to } \\
\text { extreme weather (yield) }\end{array}$ & $\begin{array}{l}\text { Ministry of Agriculture, } \\
\text { Food and Rural Affairs }\end{array}$ \\
\hline & 23 & $\begin{array}{l}\text { Vulnerability of } \\
\text { productivity of } \\
\text { apple crop }\end{array}$ & $\begin{array}{l}\text { Decrease in apple productivity due } \\
\text { to extreme weather (yield) }\end{array}$ & $\begin{array}{l}\text { Ministry of Agriculture, } \\
\text { Food and Rural Affairs }\end{array}$ \\
\hline & 24 & $\begin{array}{l}\text { Vulnerability of } \\
\text { productivity of } \\
\text { livestock }\end{array}$ & $\begin{array}{l}\text { Decrease in livestock productivity } \\
\text { due to extreme weather, decrease } \\
\text { in dairy productivity due to } \\
\text { climate change (yield) }\end{array}$ & $\begin{array}{l}\text { Ministry of Agriculture, } \\
\text { Food and Rural Affairs }\end{array}$ \\
\hline \multirow[t]{3}{*}{$\begin{array}{l}\text { Water } \\
\text { management }\end{array}$} & 25 & $\begin{array}{l}\text { Vulnerability of } \\
\text { flood } \\
\text { regulation }\end{array}$ & Records of flood inundation (area) & $\begin{array}{l}\text { Korea Water Resources } \\
\text { Corporation, Ministry } \\
\text { of Land, Infrastructure } \\
\text { and Transport }\end{array}$ \\
\hline & 26 & $\begin{array}{l}\text { Vulnerability of } \\
\text { water } \\
\text { utilization }\end{array}$ & $\begin{array}{l}\text { Records of water supply decrease } \\
\text { due to drought (amount) }\end{array}$ & $\begin{array}{l}\text { Korea Water Resources } \\
\text { Corporation, Ministry } \\
\text { of Land, Infrastructure } \\
\text { and Transport }\end{array}$ \\
\hline & 27 & $\begin{array}{l}\text { Vulnerability of } \\
\text { water quality }\end{array}$ & Budget for water purification (cost) & $\begin{array}{l}\text { Korea Water Resources } \\
\text { Corporation, Ministry } \\
\text { of Land, Infrastructure } \\
\text { and Transport }\end{array}$ \\
\hline
\end{tabular}


Table 5 continued

\begin{tabular}{|c|c|c|c|c|}
\hline Fields & No. & Item & $\begin{array}{l}\text { Data type for validation } \\
\text { (unit) }\end{array}$ & Source of data \\
\hline Fisheries & 28 & $\begin{array}{l}\text { Vulnerability of } \\
\text { fisheries due to } \\
\text { change in water } \\
\text { temperature }\end{array}$ & $\begin{array}{l}\text { Decrease in fishery } \\
\text { productivity due to } \\
\text { water temperature } \\
\text { change (yield) }\end{array}$ & $\begin{array}{l}\text { Ministry of Maritime Affairs and } \\
\text { Fisheries, National Fisheries } \\
\text { Research and Development } \\
\text { Institute }\end{array}$ \\
\hline \multirow[t]{4}{*}{ Disaster } & 29 & $\begin{array}{l}\text { Vulnerability of } \\
\text { infrastructure to } \\
\text { floods }\end{array}$ & $\begin{array}{l}\text { Damage of infrastructure } \\
\text { due to floods (area) }\end{array}$ & $\begin{array}{l}\text { Ministry of Land, Infrastructure and } \\
\text { Transport, National Emergency } \\
\text { Management Agency }\end{array}$ \\
\hline & 30 & $\begin{array}{l}\text { Vulnerability of } \\
\text { infrastructure to } \\
\text { heat waves }\end{array}$ & $\begin{array}{l}\text { Damage of infrastructure } \\
\text { during heat waves (cost) }\end{array}$ & $\begin{array}{l}\text { Ministry of Land, Infrastructure and } \\
\text { Transport, National Emergency } \\
\text { Management Agency }\end{array}$ \\
\hline & 31 & $\begin{array}{l}\text { Vulnerability of } \\
\text { infrastructure to } \\
\text { heavy snow }\end{array}$ & $\begin{array}{l}\text { Damage of infrastructure } \\
\text { due to heavy snow } \\
\text { (cost) }\end{array}$ & $\begin{array}{l}\text { Ministry of Land, Infrastructure and } \\
\text { Transport, National Emergency } \\
\text { Management Agency }\end{array}$ \\
\hline & 32 & $\begin{array}{l}\text { Vulnerability of } \\
\text { infrastructure to sea } \\
\text { level increase }\end{array}$ & $\begin{array}{l}\text { Damage of infrastructure } \\
\text { due to sea level increase } \\
\text { (area) }\end{array}$ & $\begin{array}{l}\text { Ministry of Land, Infrastructure and } \\
\text { Transport, Korea industrial } \\
\text { complex corporation }\end{array}$ \\
\hline
\end{tabular}

\subsection{Vulnerability maps based on field scale}

The first-grade municipalities of each item were synthesized for each field, and the resultant synthesized vulnerability map provides information about highly vulnerable areas in each field. Each field unit has an important indication for the establishment of adaptation plans and the allocation of financial resources because when establishing the climate change adaptation strategy, the government separated these seven fields considering the characteristics of government ministry. These maps were created for the present years (2001-2010) and future years (2046-2055; RCP 8.5) to compare changes in the first-grade areas resulting from climate change (Fig. 3).

The health field consists of various items directly or indirectly related to temperature and rainfall. Most municipalities showed values of 0-2 (first grade) for the present years. However, approximately $10 \%$ of the 232 municipalities showed high vulnerability to four-eight items of the health field. These vulnerable municipalities were separated into the following four types according to the property of vulnerability: (a) the climate exposure is higher than that in other municipalities, (b) the sensitivity is higher than that in other municipalities, (c) the adaptation capacity is lower than that in other municipalities, and (d) a combination of (a), (b), and (c). For example, Busan, which is located in the southern area, showed type (d) vulnerability.

Future vulnerability was assessed by using only the change in climate conditions. That is, the results were obtained by simulating future vulnerability using the present conditions of sensitivity and adaptation capacity. Items related to rainfall showed much higher vulnerability than that in the present years. The health vulnerability of Seoul, which is the capital of the ROK, showed a particularly dramatic increase in future climate conditions, which demonstrates that the present condition of the adaptation capacity may not be sufficient in the future. Moreover, Busan showed a continuously high vulnerability in the present and future years, which shows that improvement in the adaptation capacity is very important for type (d) municipalities for reducing climate impacts. 


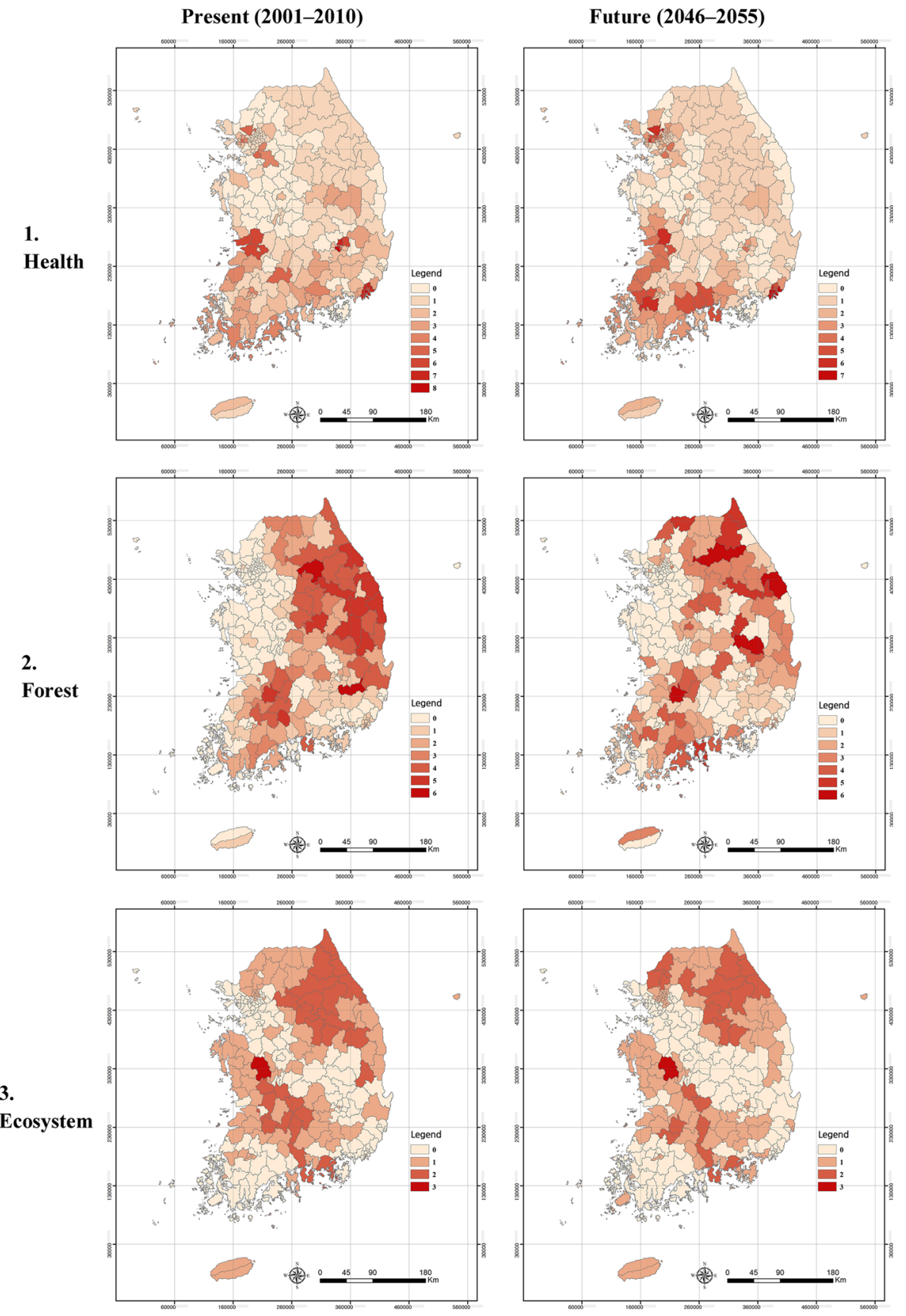

Fig. 3 Distribution of the first-grade areas for the seven fields in the present and future 

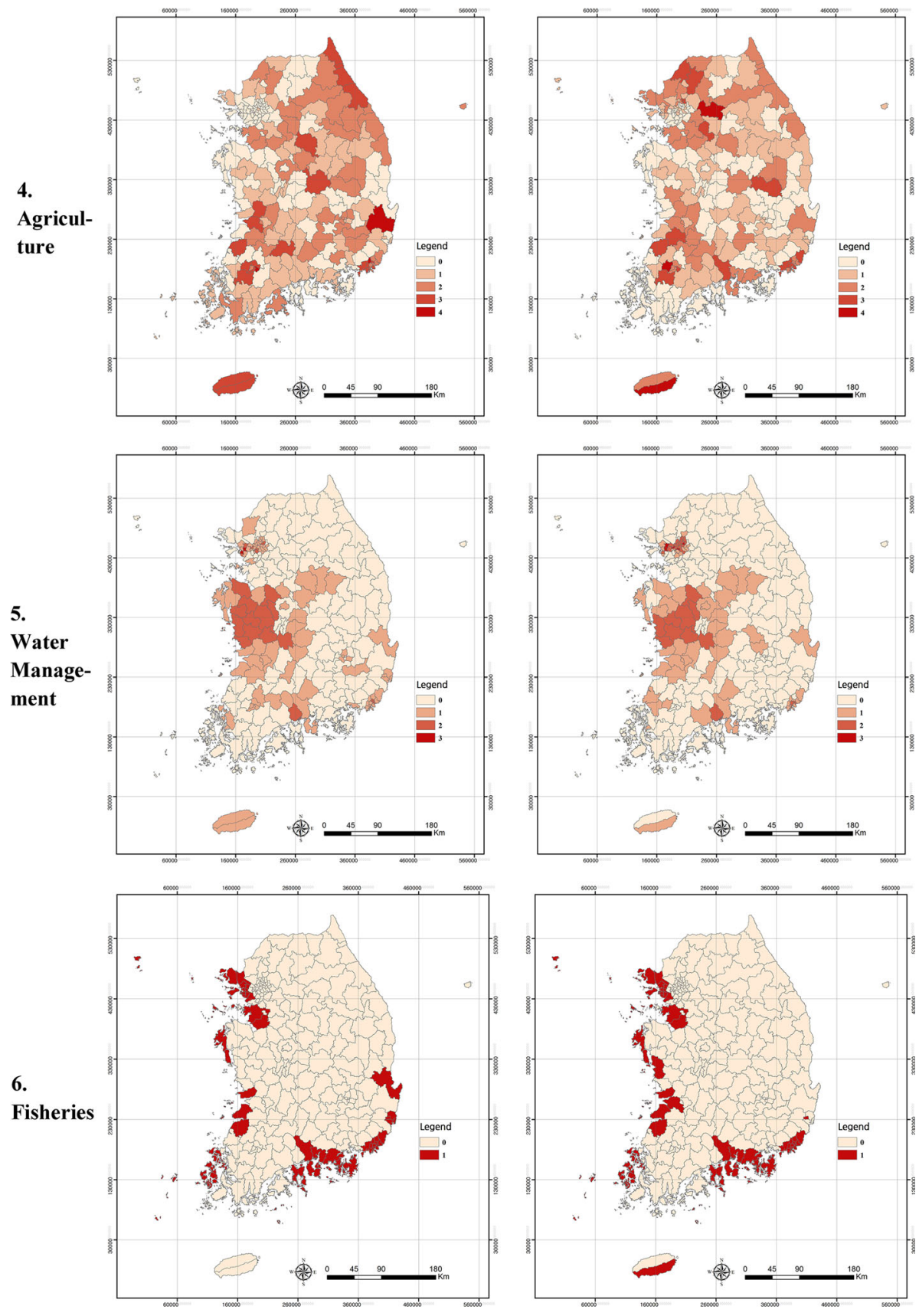

Fig. 3 continued 

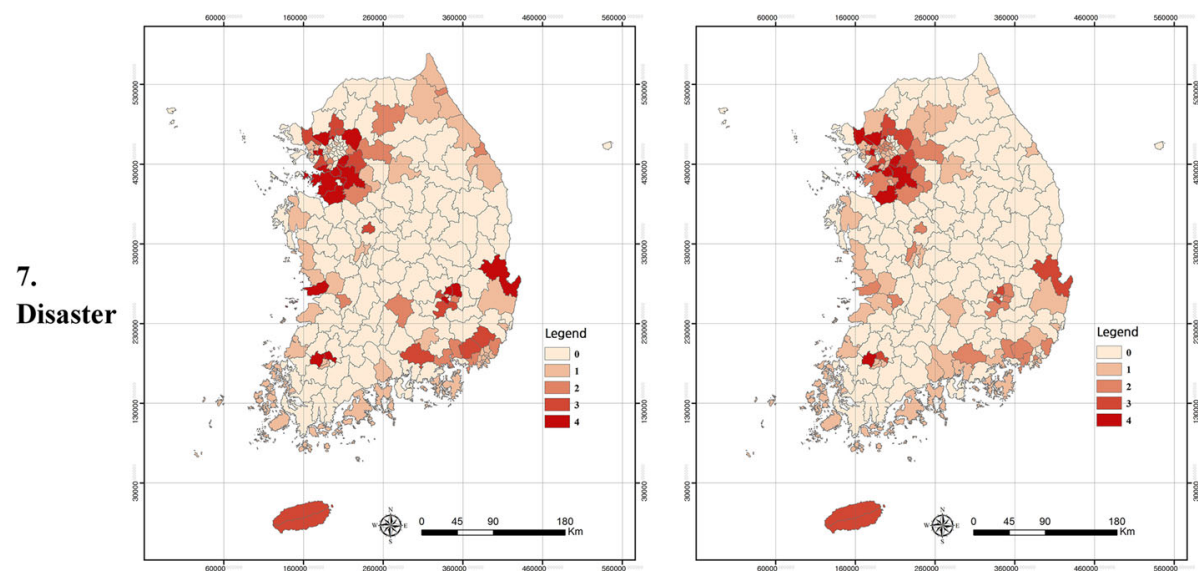

Fig. 3 continued

The forest field includes seven items that are affected by rainfall and temperature, and its vulnerability is strongly affected by areas of forest in the municipality. The eastern and southwestern areas of the ROK have more forestland than the other areas and therefore showed many first-grade vulnerability items in the present years. These highly vulnerable areas of the forest field were classified as type (a) vulnerability; therefore, these areas should extend their adaptation capacities to reduce damage related to forests.

The future vulnerability of the forest was increased for items related to rainfall such as landslide, vulnerability of trails, drought, and forest fire. The reason for the increase in some eastern areas that showed much higher vulnerability than that in the present years was determined to be the increased prevalence of extreme weather such as heavy rainfall and severe drought.

The ecosystem field had three items for vulnerability assessment, all of which were related to long-term changes in rainfall and temperature. The areas with high ecological value were determined to have higher vulnerability than other area and were classified as type (a) vulnerability. The eastern and southwestern areas had many first-grade vulnerable areas, similar to that in the forest field. The vulnerability was more highly affected by sensitivity variables than climate exposure and adaptation capacity. The distribution of first-grade areas did not change significantly in the future because the sensitivity is more important than climate conditions for the ecosystem field.

Five items were included in the agriculture field. Productivity of rice, apples, and livestock was related to gradual changes in rainfall and temperature. The other two items, erosion of farmlands and damage to cultivation facility, were related to extreme weather such as heavy rainfall. The first-grade areas of the agriculture field were classified as type (d) vulnerability. Thus, the items were similarly affected by all three characteristics of climate exposure, sensitivity, and adaptation capacity.

The water management field included three items. Flood and water utilization were related mainly to rainfall variables, and water quality was related to temperature and rainfall. However, the adaptation capacity is a more important factor than climate exposure for assessing vulnerability in this field. The vulnerable municipalities of water management were classified as type (c) vulnerability. 

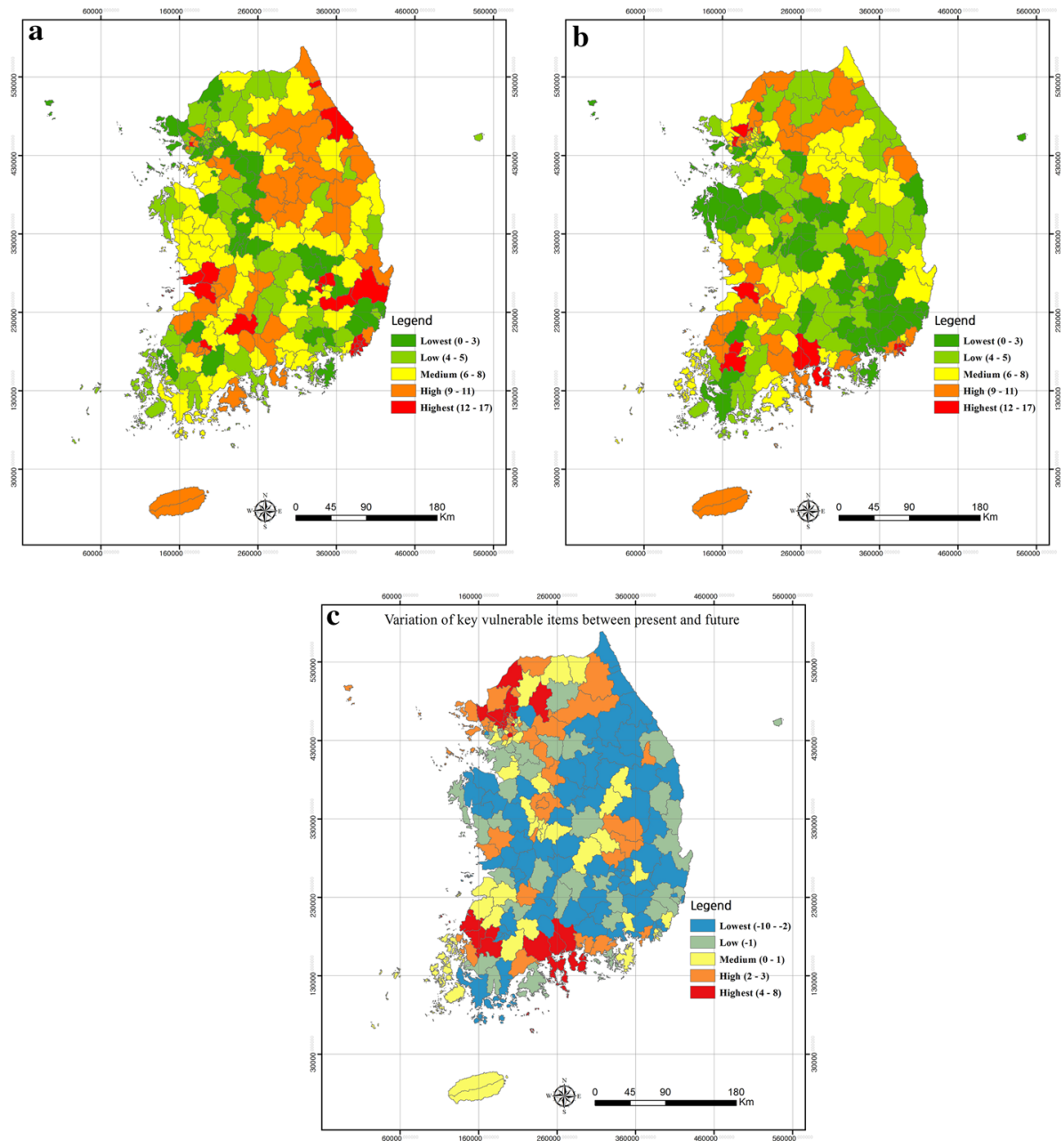

Fig. 4 Key vulnerability areas of the seven fields

The first-grade areas are concentrated in the capital area and western areas at the present. The capital area vulnerability is due to its high population density, and the western areas are vulnerable to water management because most of the rivers are located in the eastern areas of the ROK. The future vulnerability did not differ significantly from that of the present according to the important role of the adaptation capacity.

The fisheries field focused on assessing the negative effects of the increase in water temperature, and the analysis targets were limited to municipalities near the sea. The western and southern areas showed higher vulnerability than other areas. Climate exposure and sensitivity are important factors for this field; therefore, it was categorized as both (a) and (b) types. The future vulnerability showed a distribution similar to that of the present.

The disaster field focused on damages to infrastructure, and all of the items were strongly affected by climate exposure and sensitivity, and the vulnerable areas were 
classified as (a) and (b) vulnerability types. The capital area showed many first-grade items because of its greater infrastructure relative to other municipalities. Some municipalities in the southeastern areas showed high vulnerability due to sensitivity variables related to areas of infrastructure, and the future vulnerability was similar to that of the present. These results indicate that sensitivity is a more important factor than climate exposure in the disaster field.

\subsection{Key vulnerable areas of the seven fields}

The first-grade maps of each field were aggregated as synthesis maps to describe the most vulnerable areas of the present and future years (Fig. 4a, b) in order to support the government program. The government has the authority to allocate financial resources for establishing adaptation plans. Government decision makers can utilize these synthesis maps to determine the most urgent needs of municipalities in the establishment of adaptation plans.

The classification of the first-grade areas in the synthesis map was used to compare the relative vulnerability among municipalities. The highest grade includes 12-17 items assessed as first grade (Fig. 4a, b). The northeastern, southwestern, and southeastern areas had the highest grade of municipalities at the present including 9-11 items distributed in the northeastern and southwestern areas (Fig. 4a).

The main reasons for these high-grade areas are the health, forest, agriculture, and disaster fields, which showed distributions similar to those in the present first-grade map. Highly vulnerable municipalities that were assessed with the highest and high grades showed all vulnerability types, although type (c) was the most common. Moreover, the municipalities of type (c) vulnerability showed the highest grade in the future synthesis map (Fig. 4b). Thus, the municipalities that had a high climate exposure and sensitivity and low adaptation capacity showed the greatest vulnerability to climate change impacts.

The variation map shows different values of a number of first-grade items between the present and future years (Fig. 4c). This map helps to easily identify municipalities in which first-grade items are abruptly increased in the future. The highest grade municipalities appeared in the northwestern and southwestern areas of the ROK, where the climate exposure increased in the future, and the adaptation capacity was relatively low. The lowest grade municipalities showed highest or high grades at the present.

\section{Conclusions}

This study used a combination of quantitative and qualitative methods for vulnerability assessment of 32 items in 7 fields in 232 municipalities. The suggested framework can reduce the subjectivity and clarify the assessment process because the variables, weights, and integration method are explicit ("Appendix"). Therefore, all operators can obtain the same results as those reported in this study, and readers can understand the exact results and methods used (Jeffers 2013; Wang et al. 2013). Equations (2) and (3) reflect the direct impact of weights on variables by following the basic concept of vulnerability (Adger and Vincent 2005).

Setting priorities and allocating resources are the most difficult processes for the government in adapting to climate change (Allison et al. 2009; Tran et al. 2010; IPCC 2012; 
Frazier et al. 2014), and identification of the most urgent municipalities poses further challenges. Thus, information about the priority of vulnerability is helpful for allocating financial resources to highly threatened municipalities. In this context, the present study can provide useful knowledge and serve as an important basis in establishing adaptation plans. By using the results of this vulnerability assessment, decision makers can clearly identify vulnerable areas, vulnerable fields of a particular municipality, and the reason for the vulnerability. Moreover, this study can be utilized as a reference or a basic tool for more specific vulnerability assessments than those on the national scale.

Readers should consider that the vulnerability indices cannot provide objective values or absolute vulnerabilities. The Delphi method, one of the important methods used in this study, is an effective tool for reaching a consensus value; however, it cannot provide objective weights. Additionally, only the climate conditions are changed in the future vulnerability assessment even though damage can have a significantly stronger dependence on other conditions such as land surface modification (Bonachea et al. 2010; Bruschi et al. 2013). This limitation is attributed to the lack of future environmental and socioeconomic data. Although several studies have predicted changes in socioeconomic information for the ROK, the results have not been validated and have a large amount of uncertainty (Lee et al. 2007; Park et al. 2007; Kim et al. 2013; Ryu et al. 2014). Therefore, the government of the ROK analyzed future vulnerability by using only future climate data. This method has merit in identifying negative and positive effects according to changes in climate condition (Kim et al. 2015). However, improvement is needed in further studies to obtain more reliable results.

Acknowledgments This work was supported by the Climate Change Vulnerability Assessment of Local Government for Establishment of Adaptation Plan project (Korea Environment Institute, National Institute Environmental Research), the 2015 BK 21 Plus Project (Seoul National University Interdisciplinary Program in Landscape Architecture, a global leadership program toward innovative green infrastructure), the Development of Economic Assessment Technique for Climate Change Impact and Adaptation Considering Uncertainties (Korea Ministry of Environment, Project No. 2014001310010), the Development of Climate Change Adaptation, Management Techniques, and Supportive System (Korea Ministry of Environment, Project No. 416-111-014), the Development of Climate Change Policy Supporting Model for Impact Assessment and Adaptation Planning (Korea Ministry of Environment, Project No. 2014001310005).

Open Access This article is distributed under the terms of the Creative Commons Attribution 4.0 International License (http://creativecommons.org/licenses/by/4.0/), which permits unrestricted use, distribution, and reproduction in any medium, provided you give appropriate credit to the original author(s) and the source, provide a link to the Creative Commons license, and indicate if changes were made.

\section{Appendix}

See Table 6. 


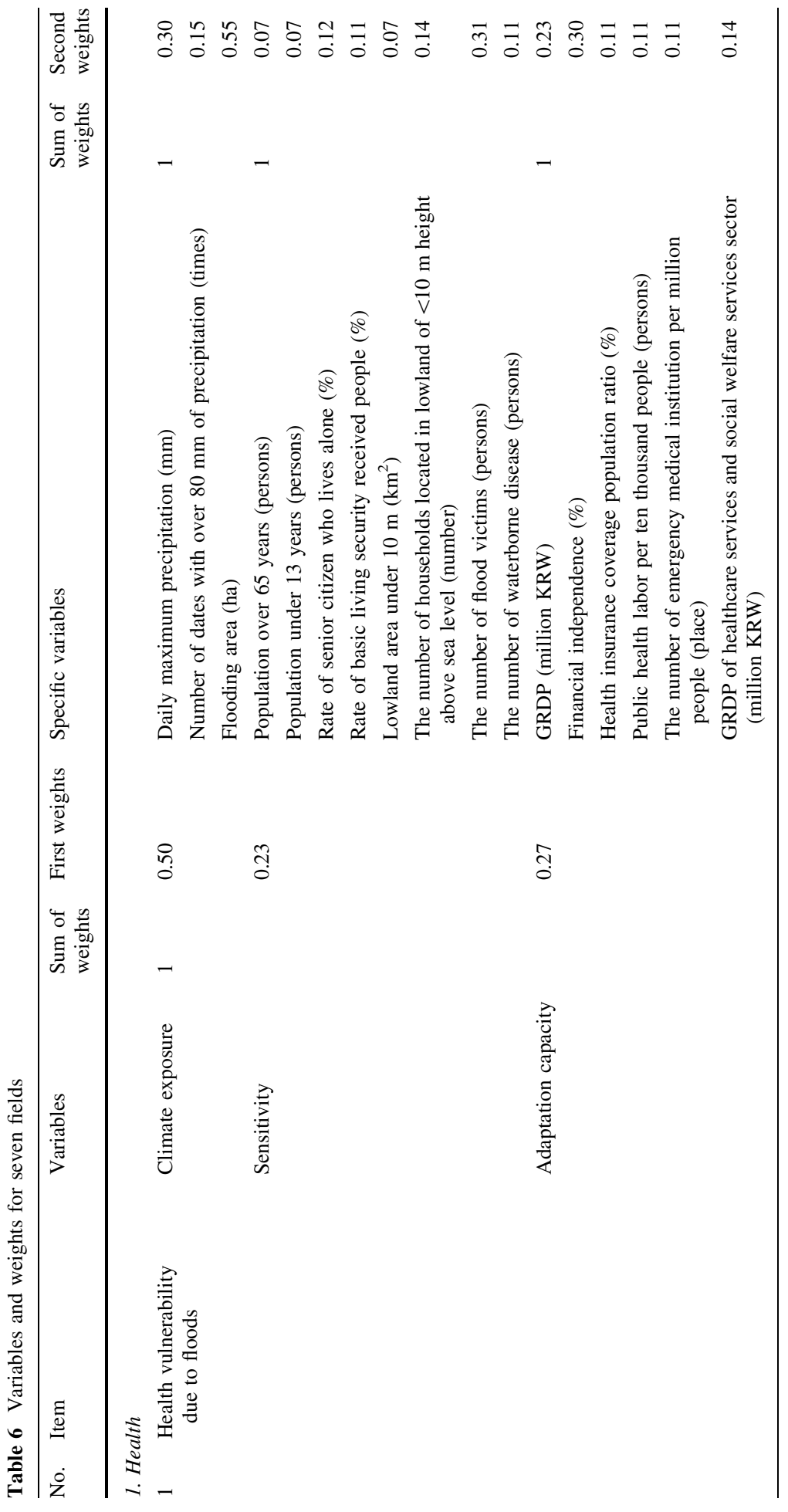




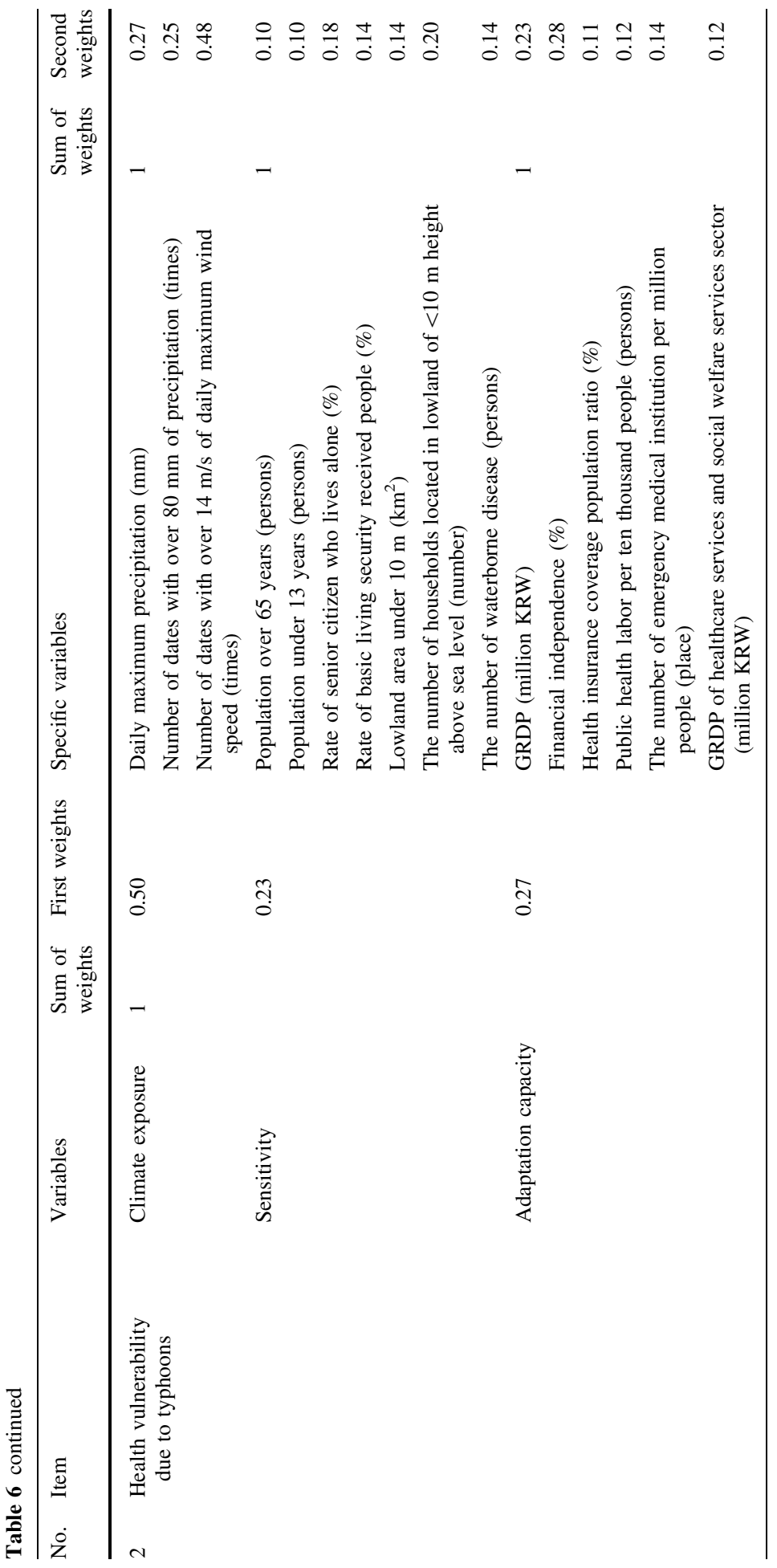




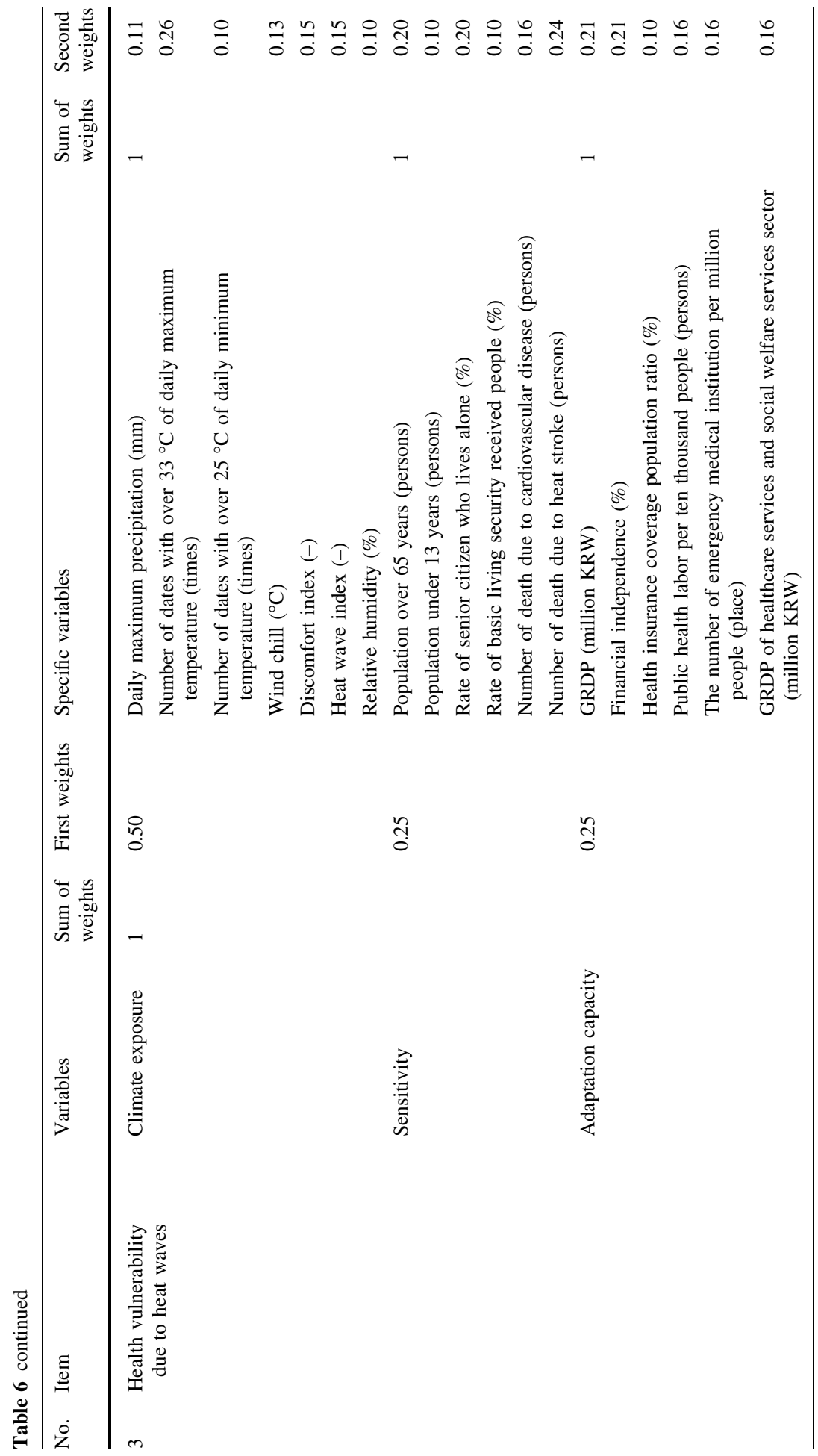




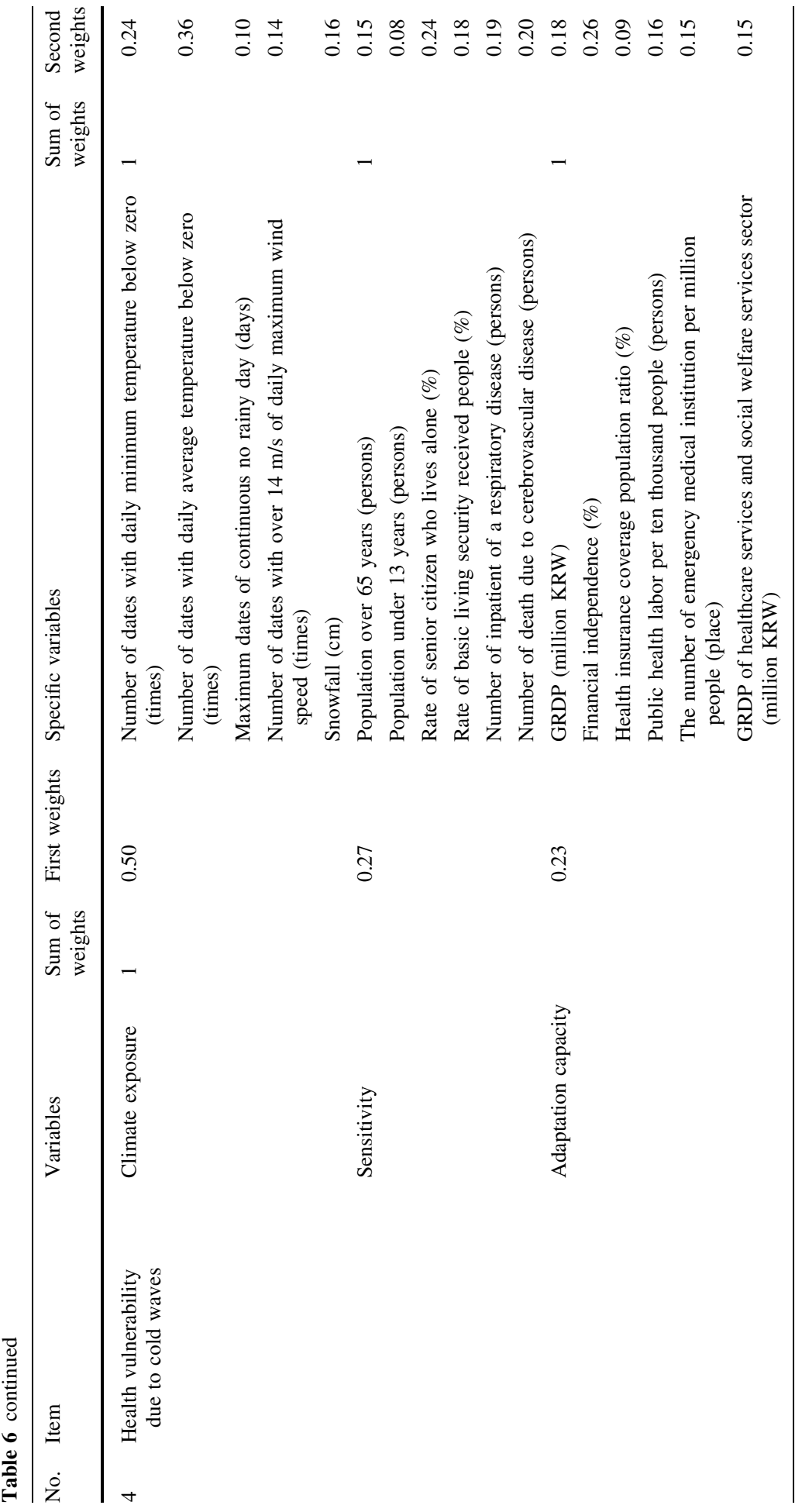




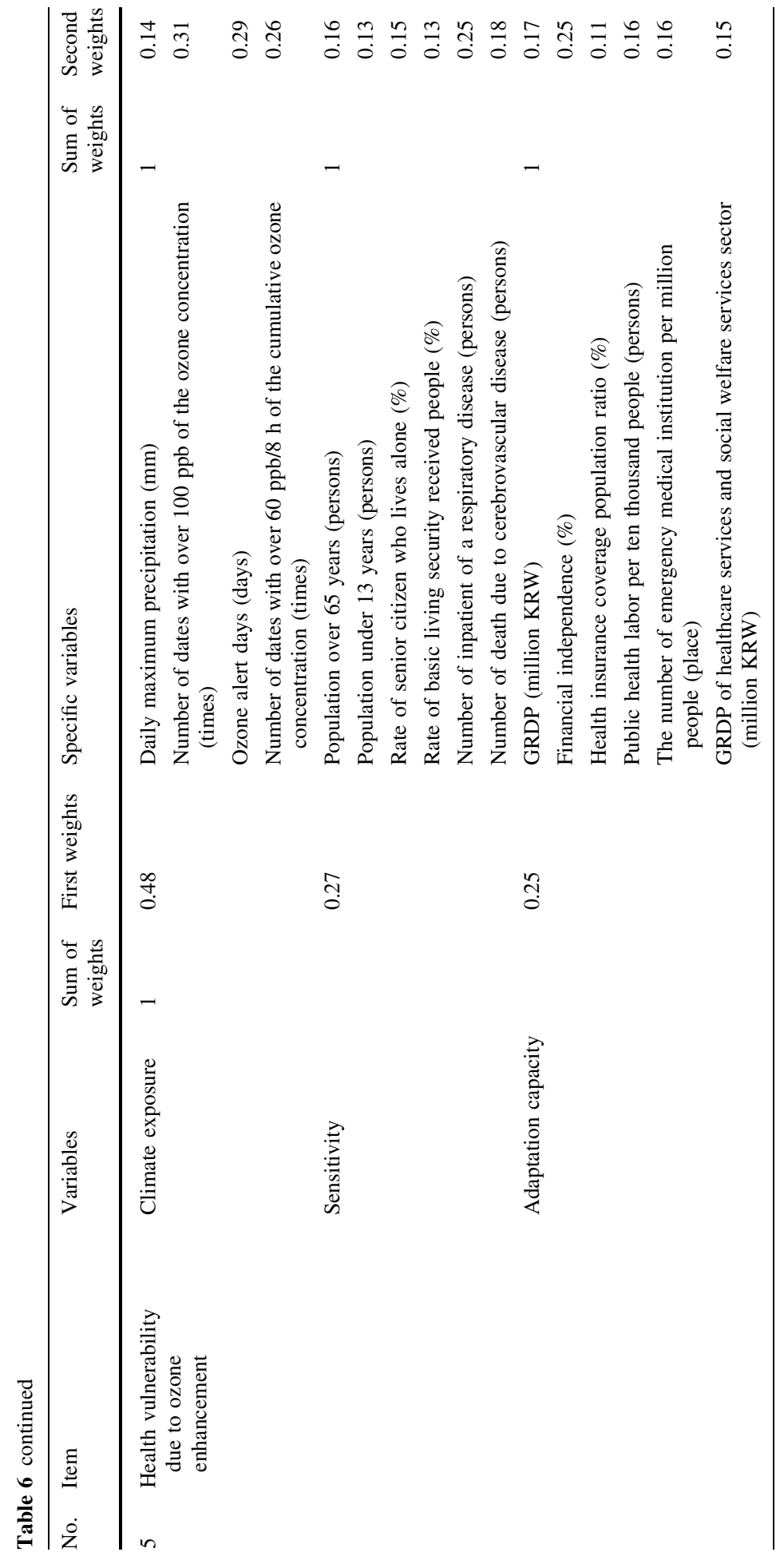




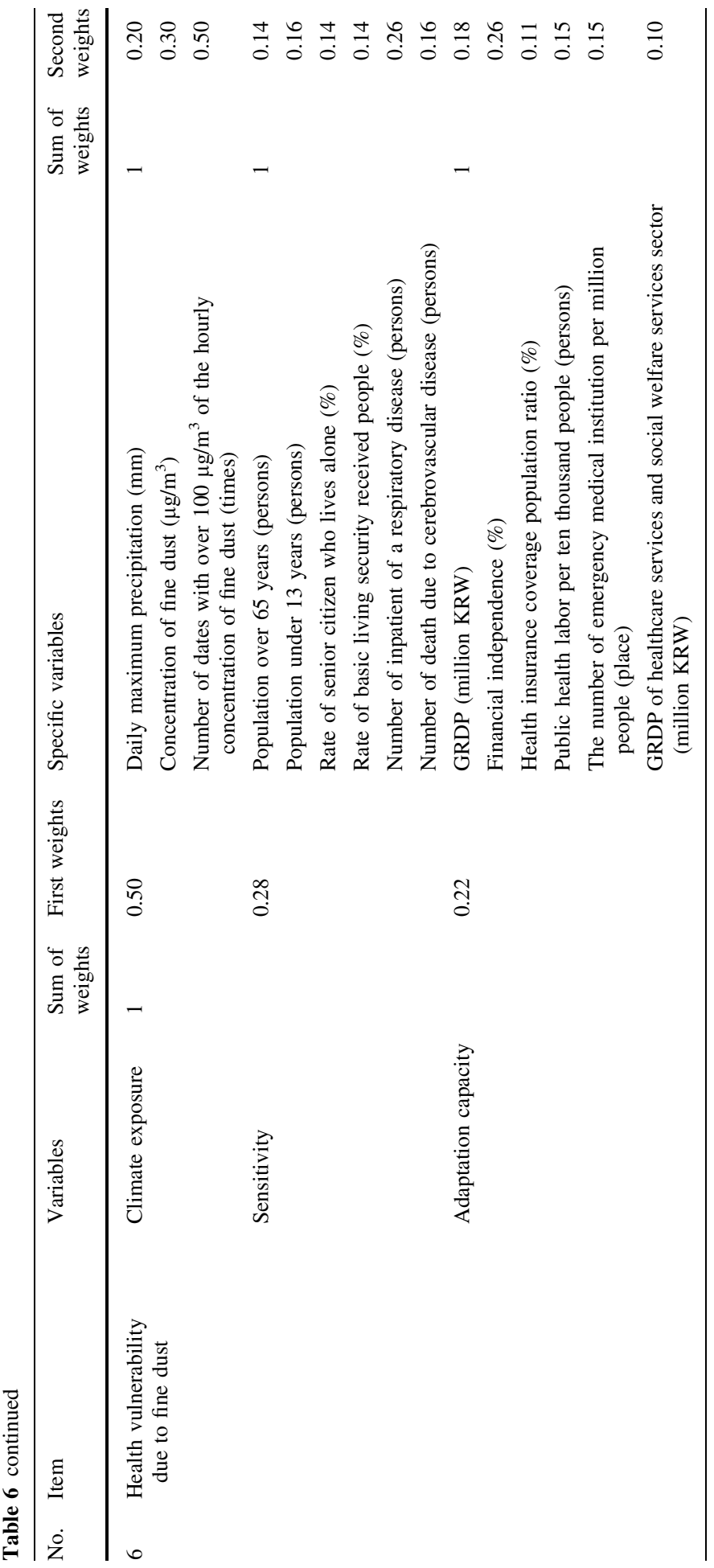




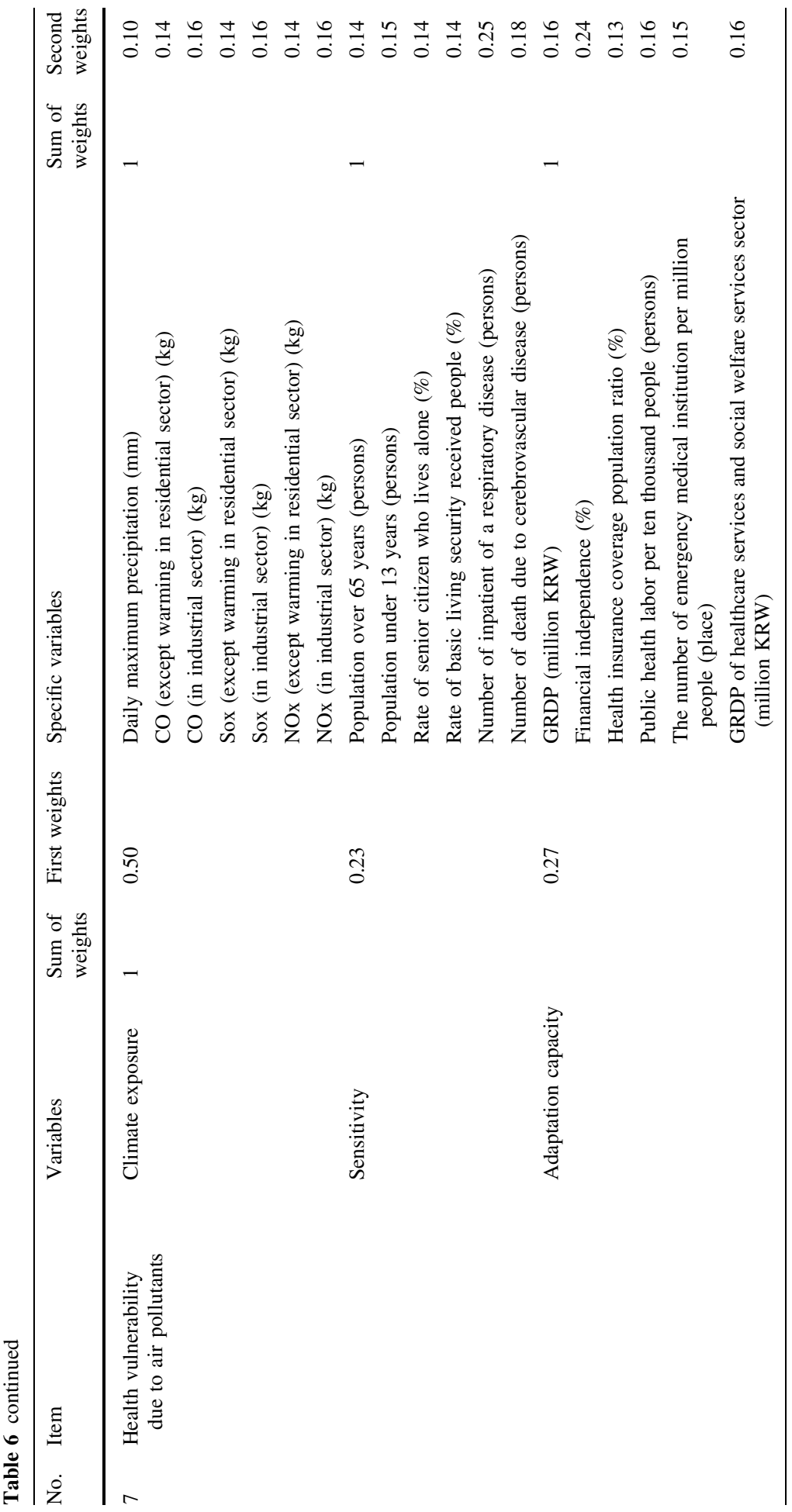




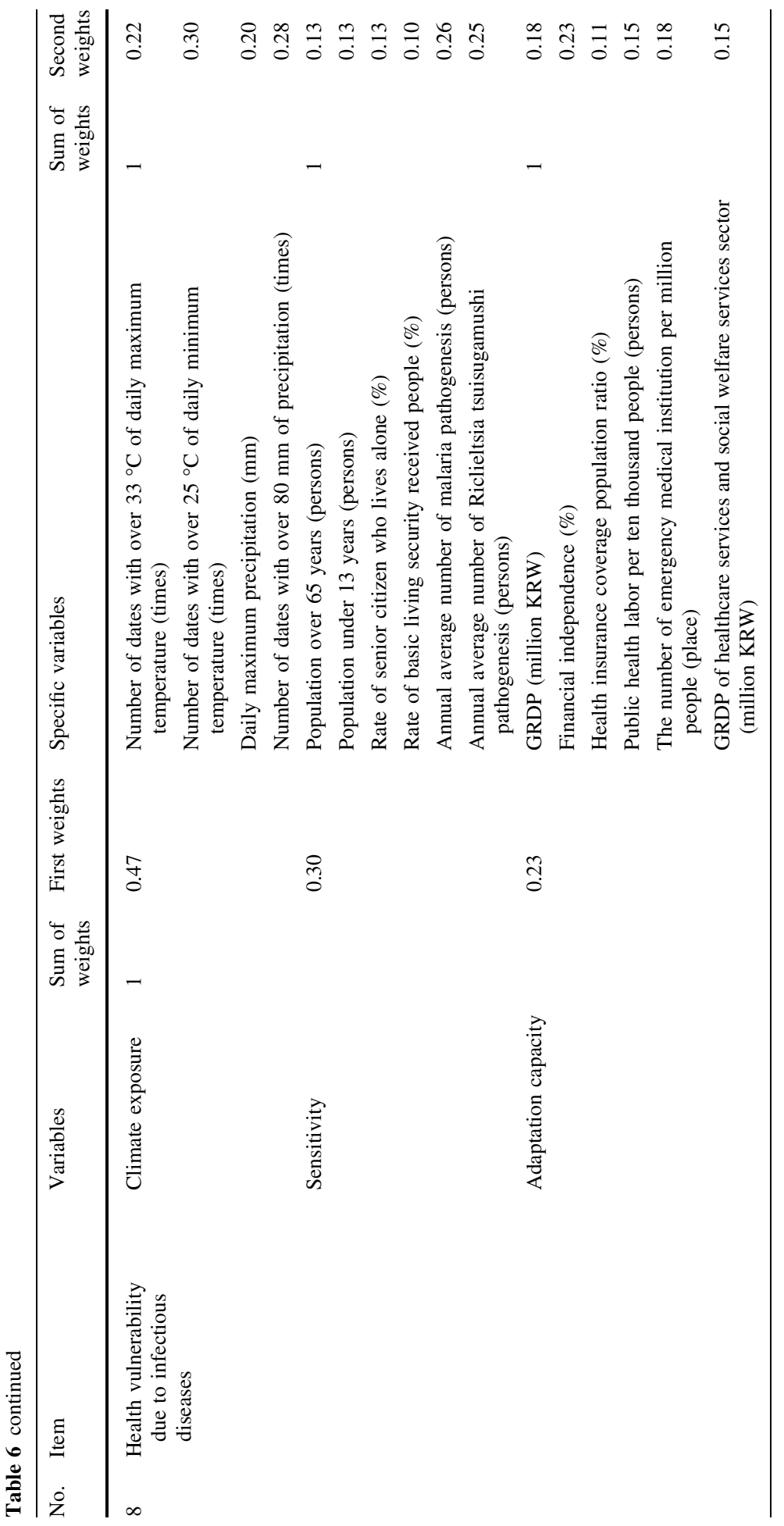




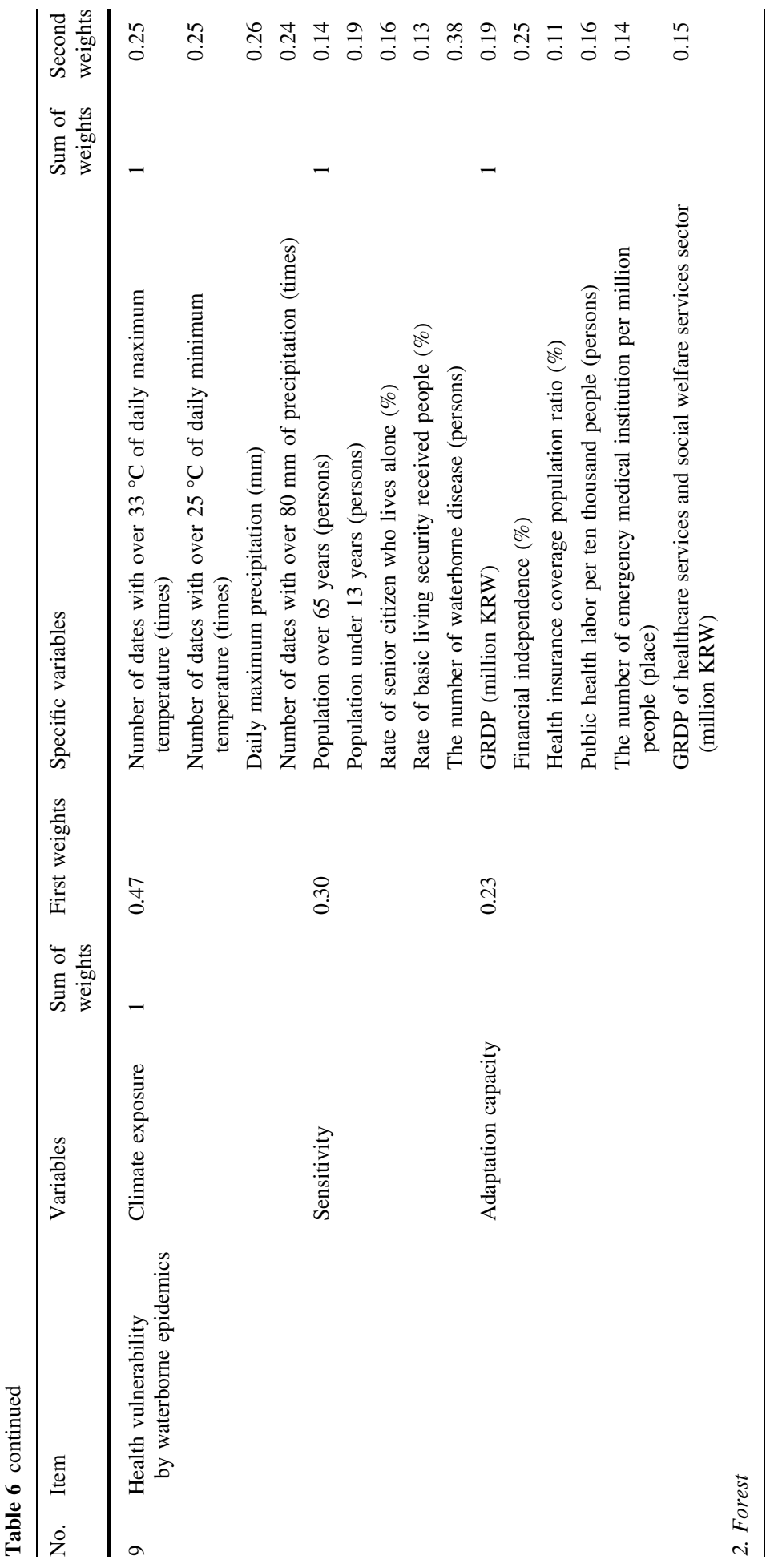




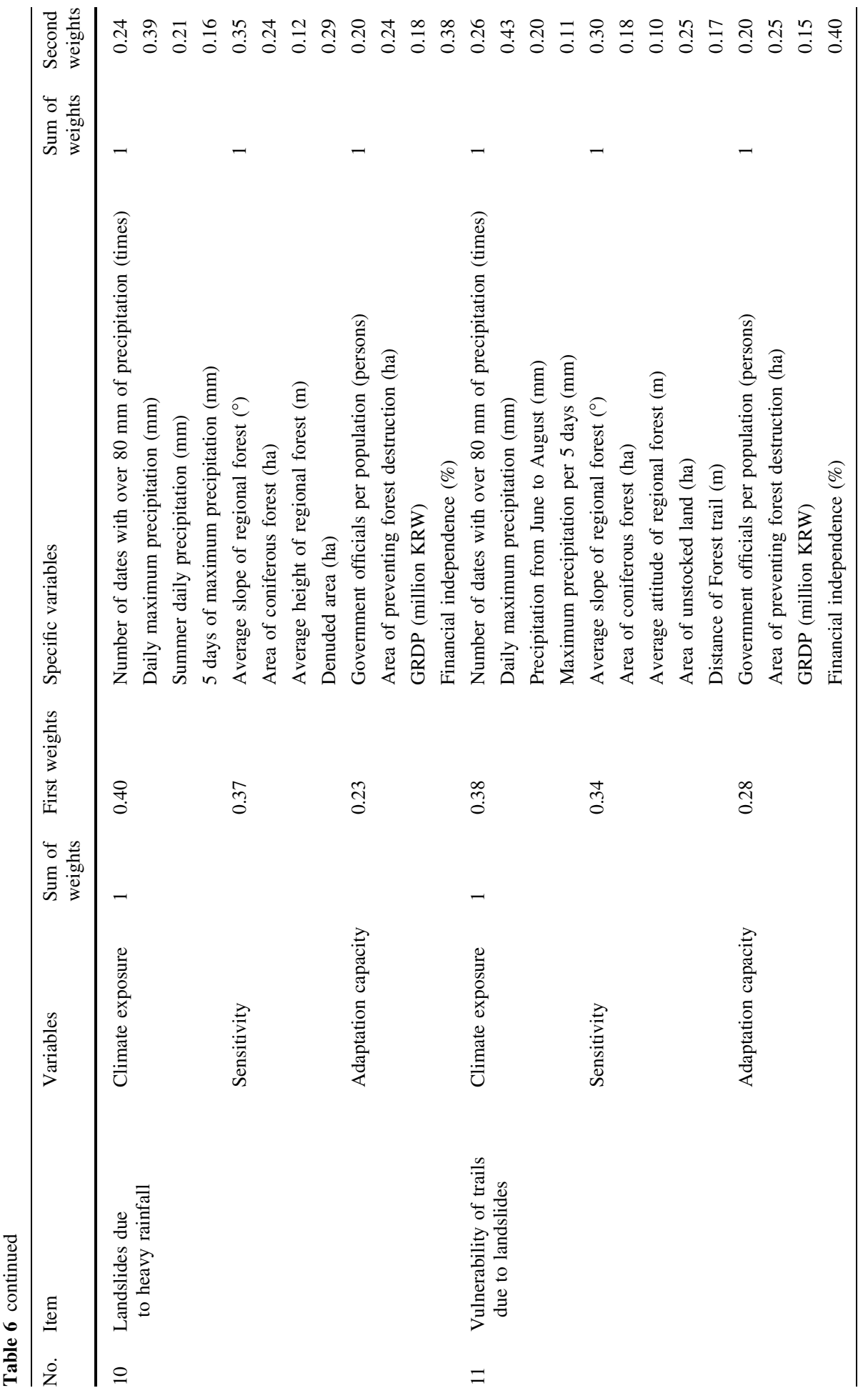




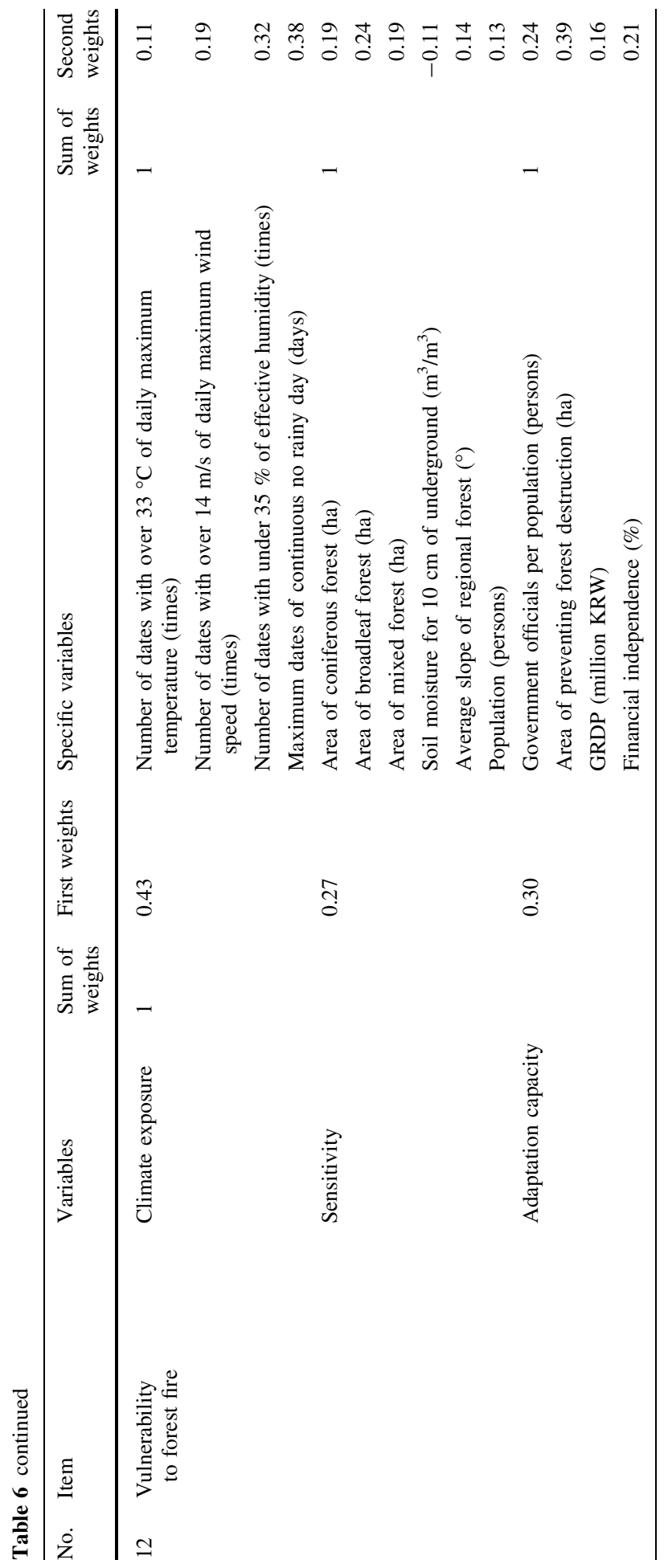




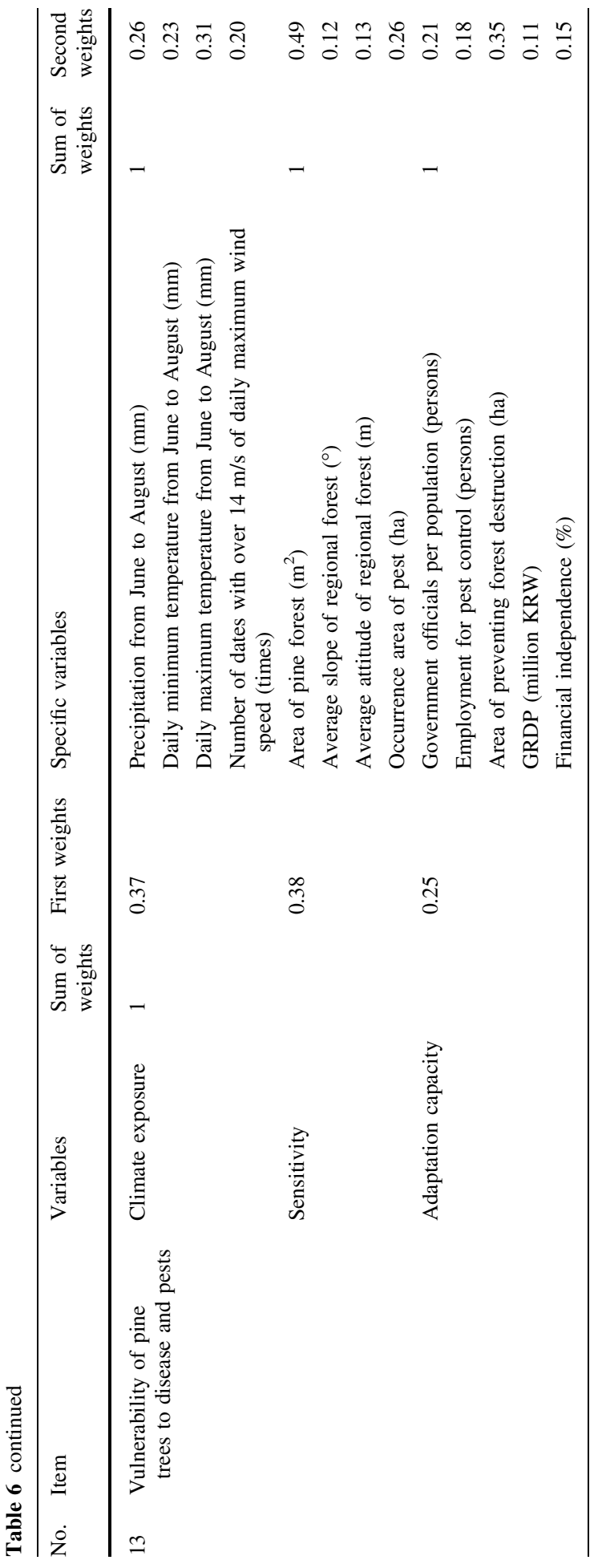




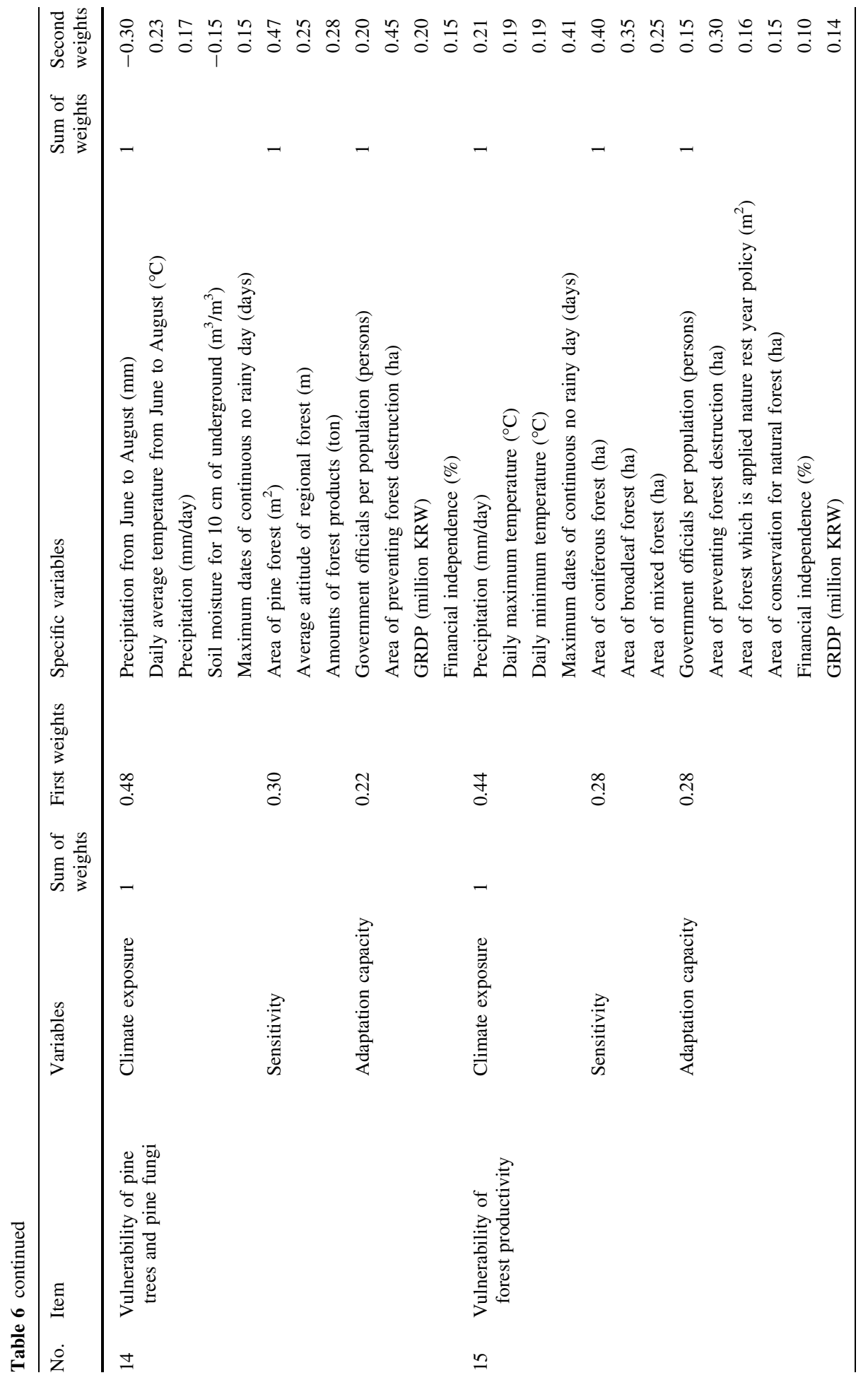




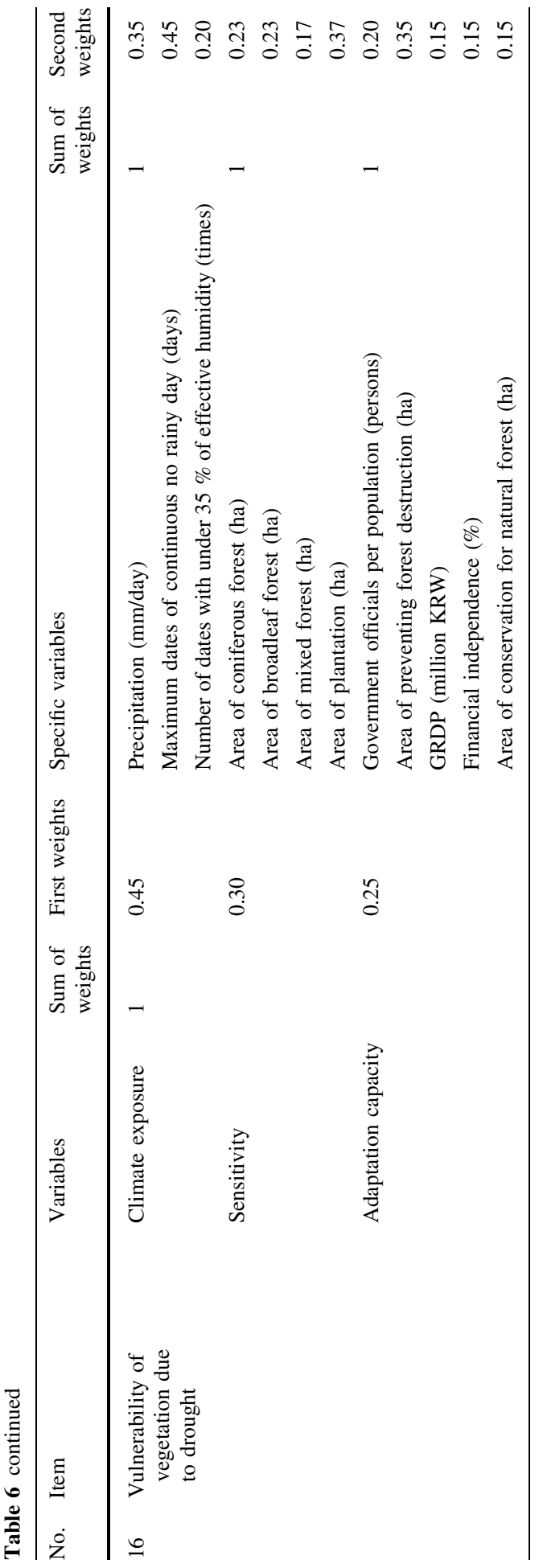

照 Springer 


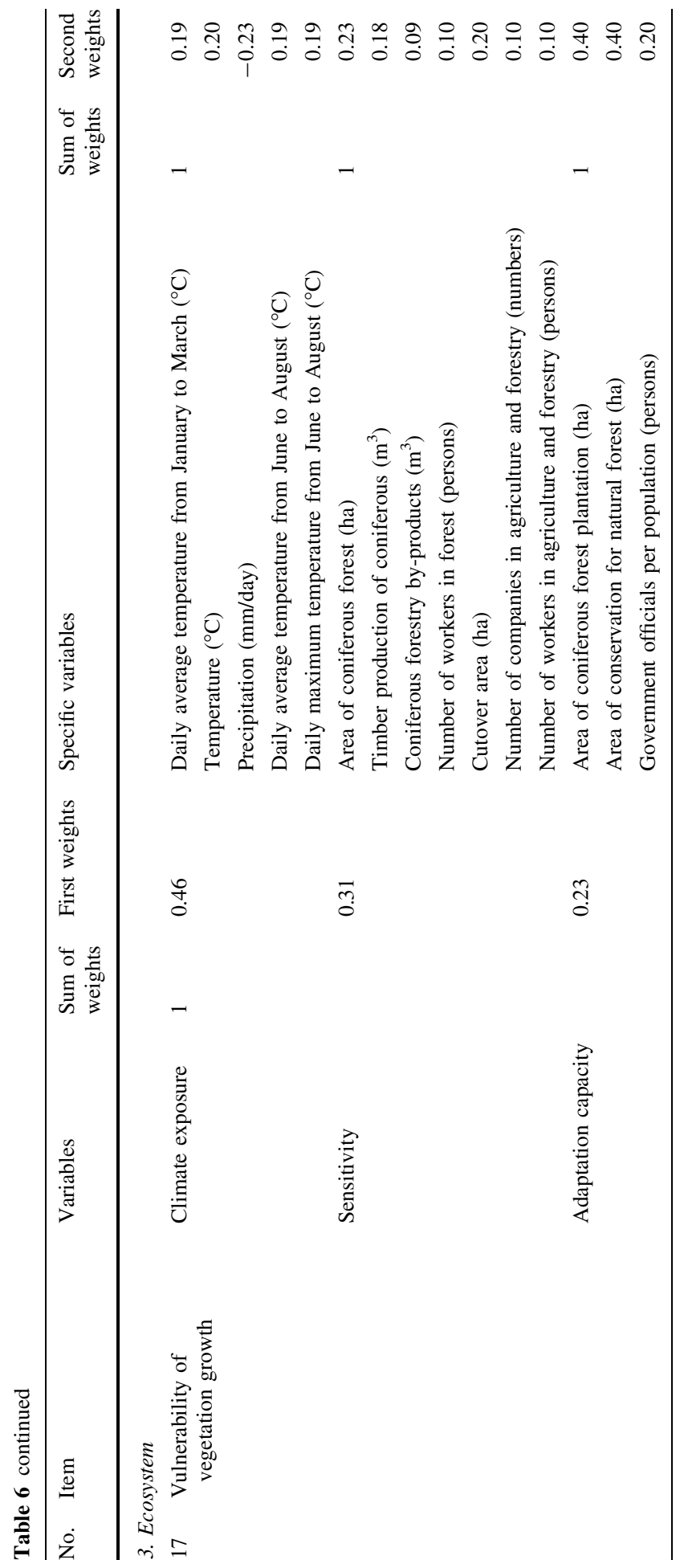




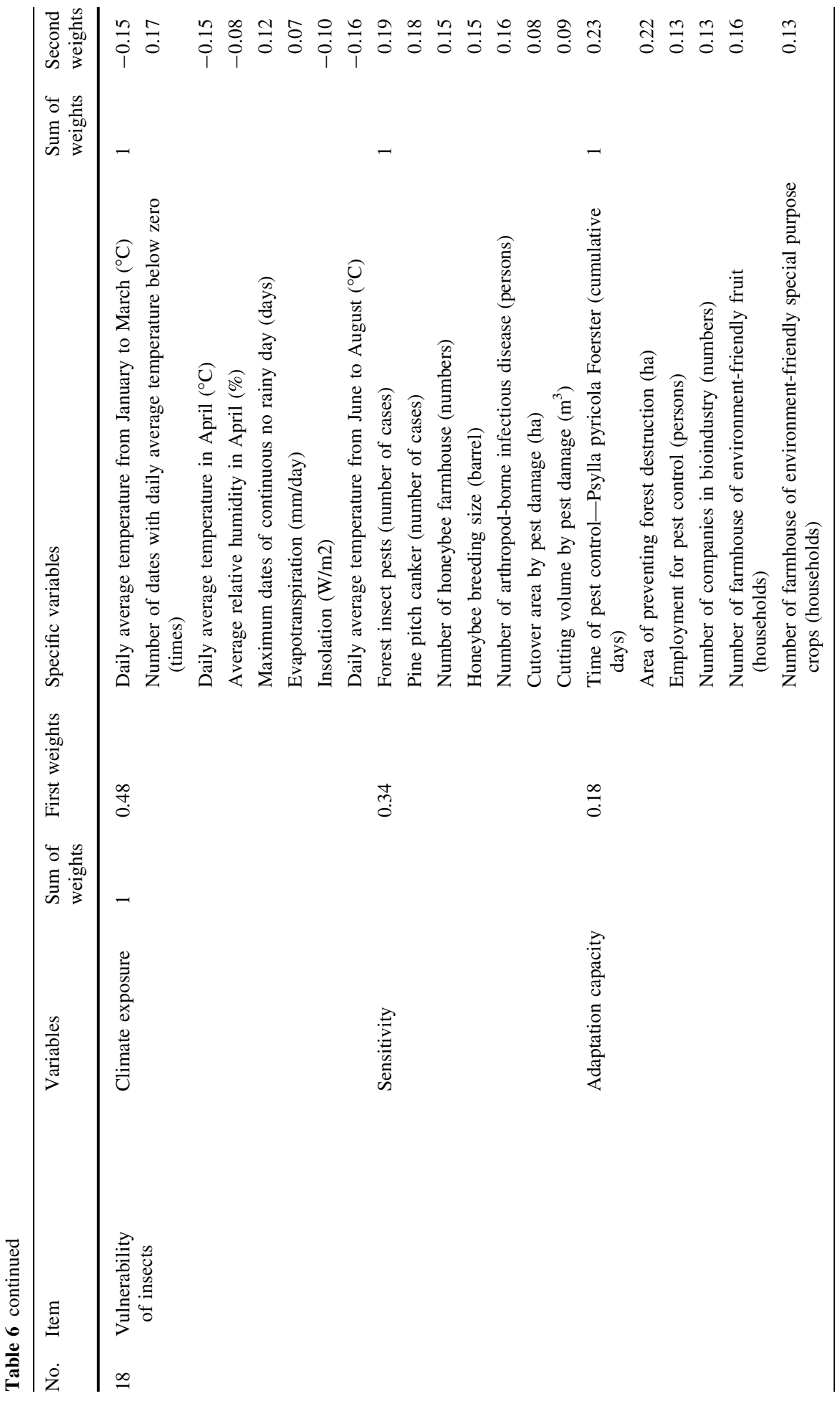




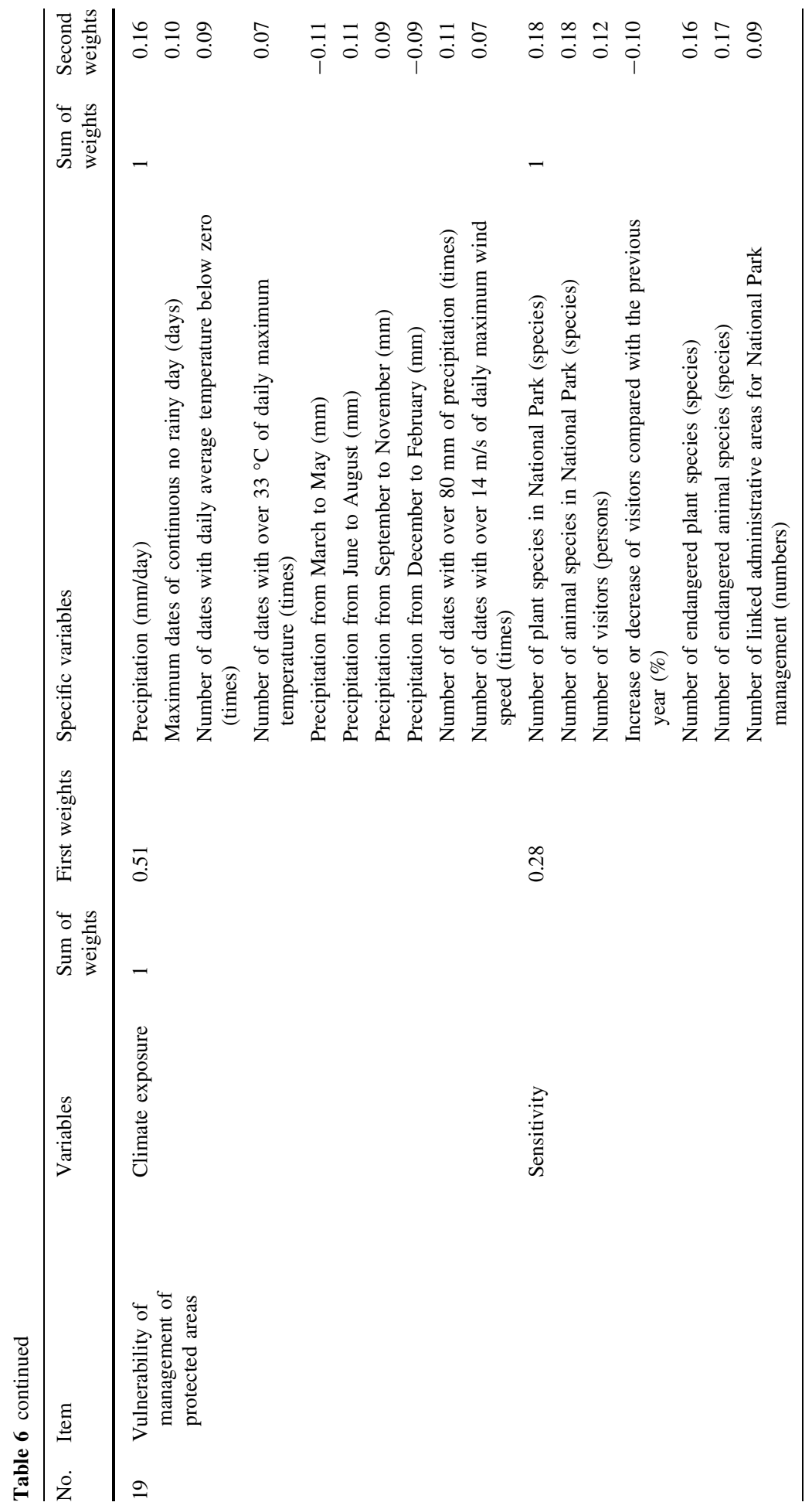




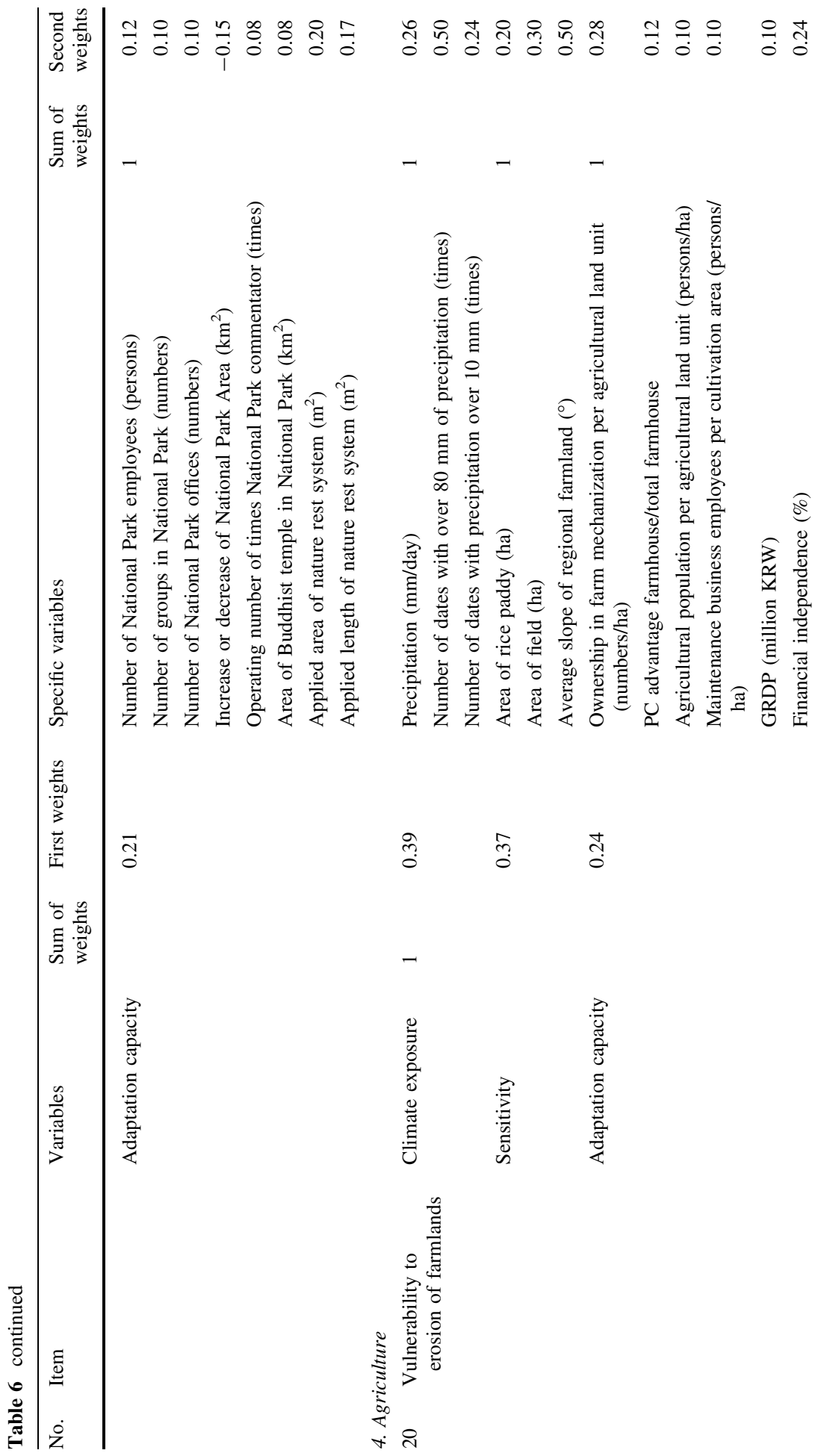




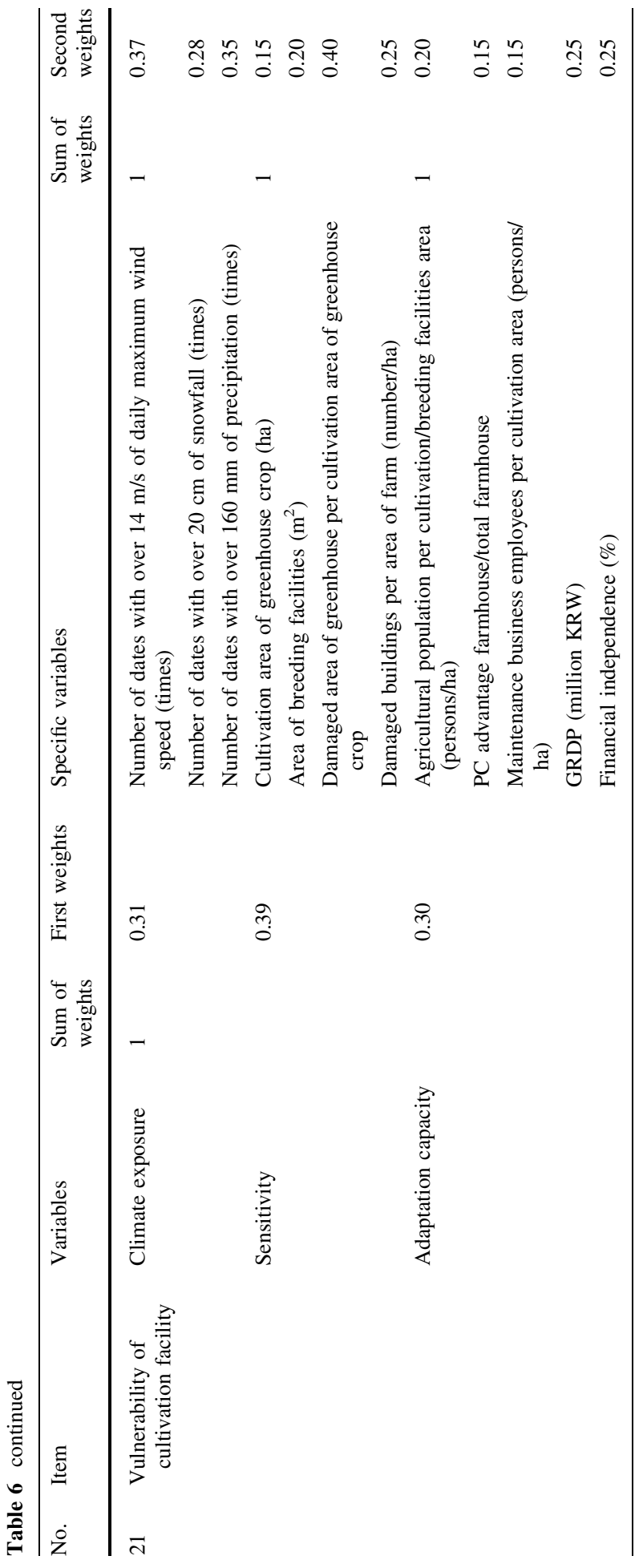




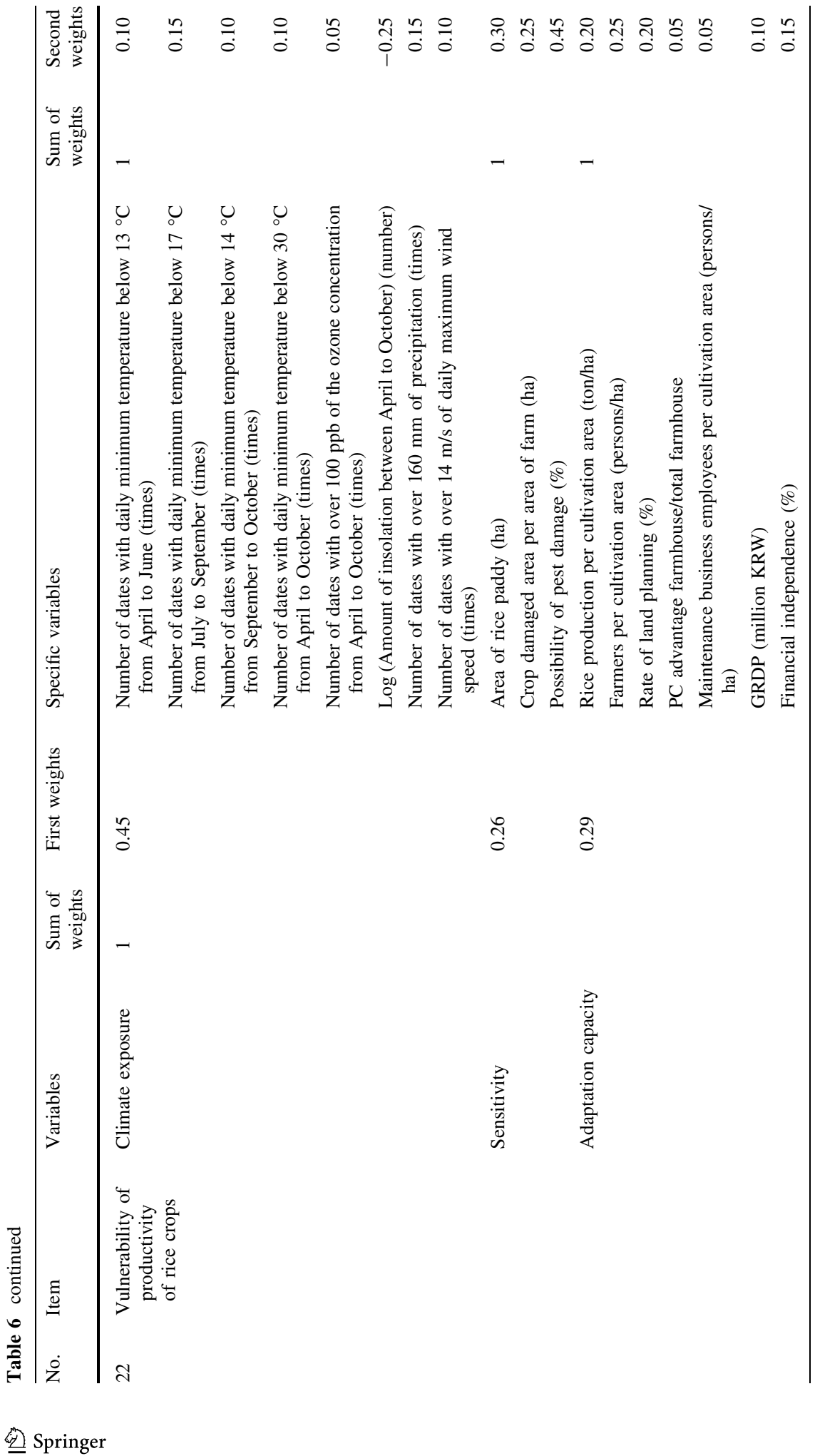




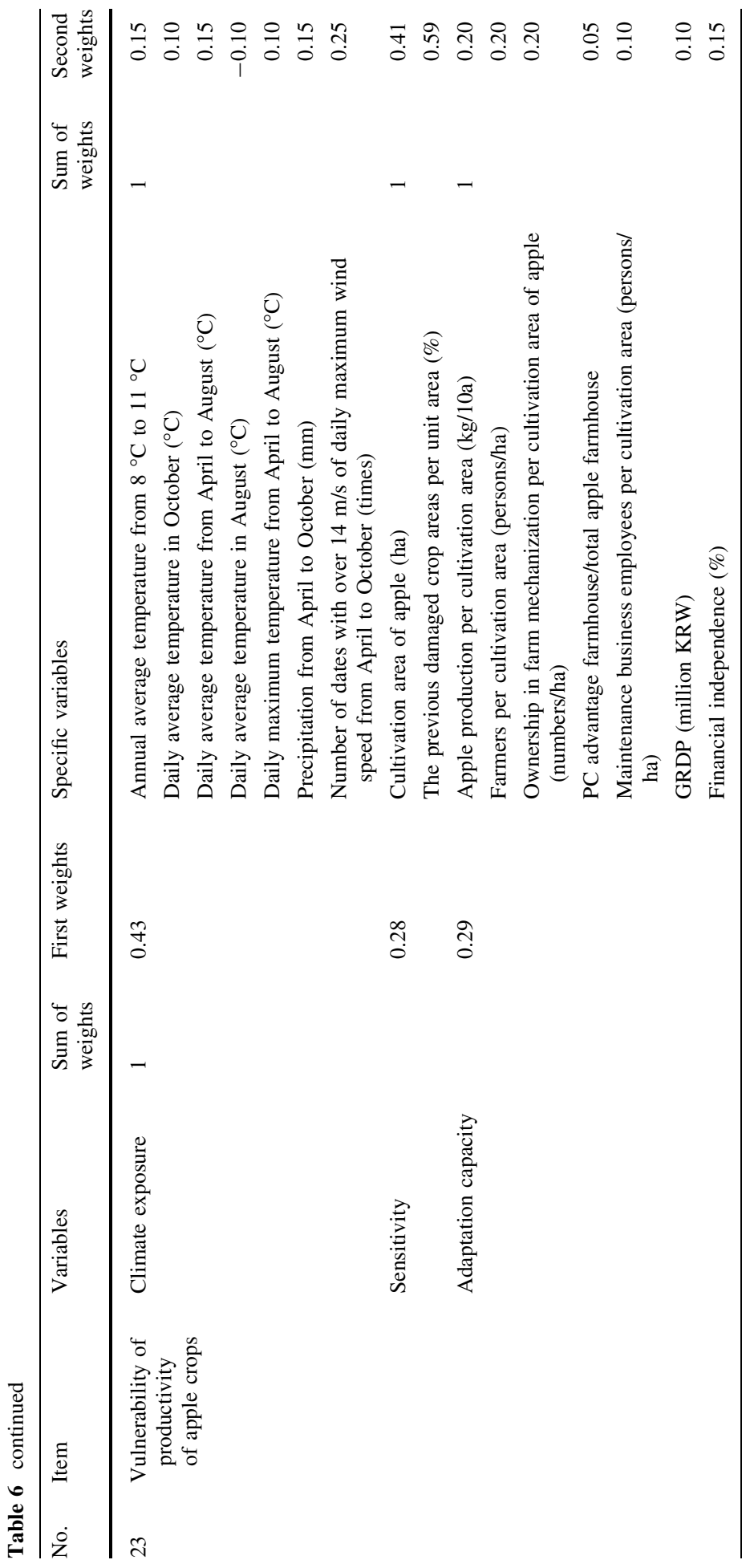




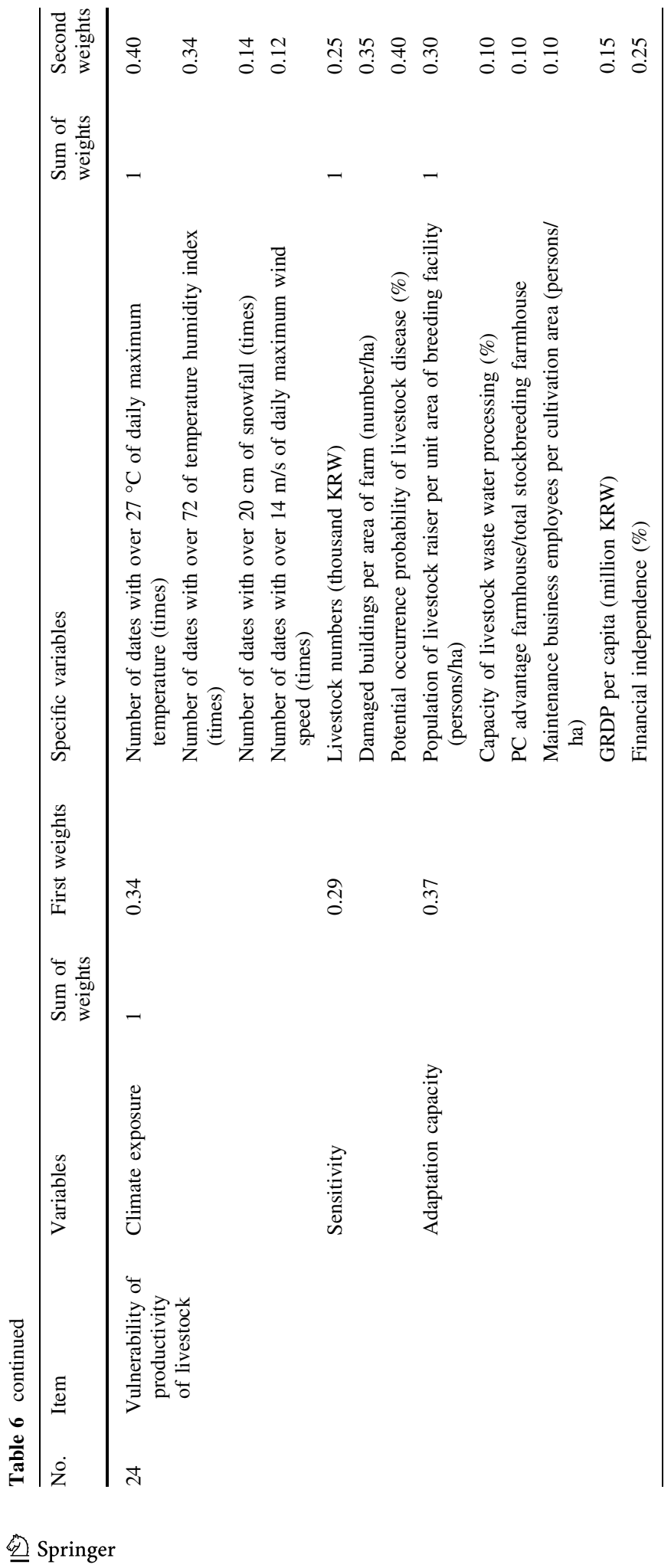




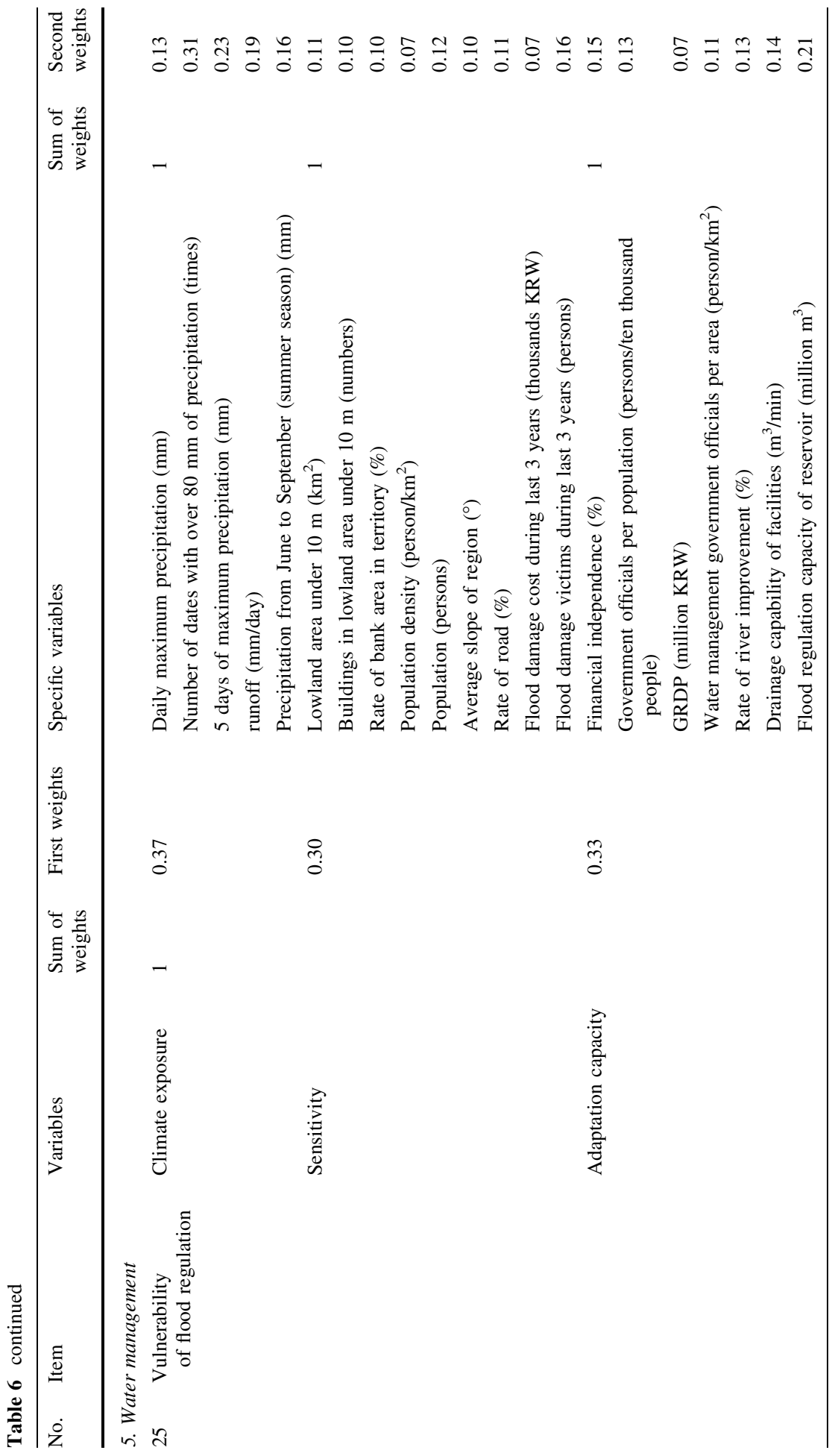




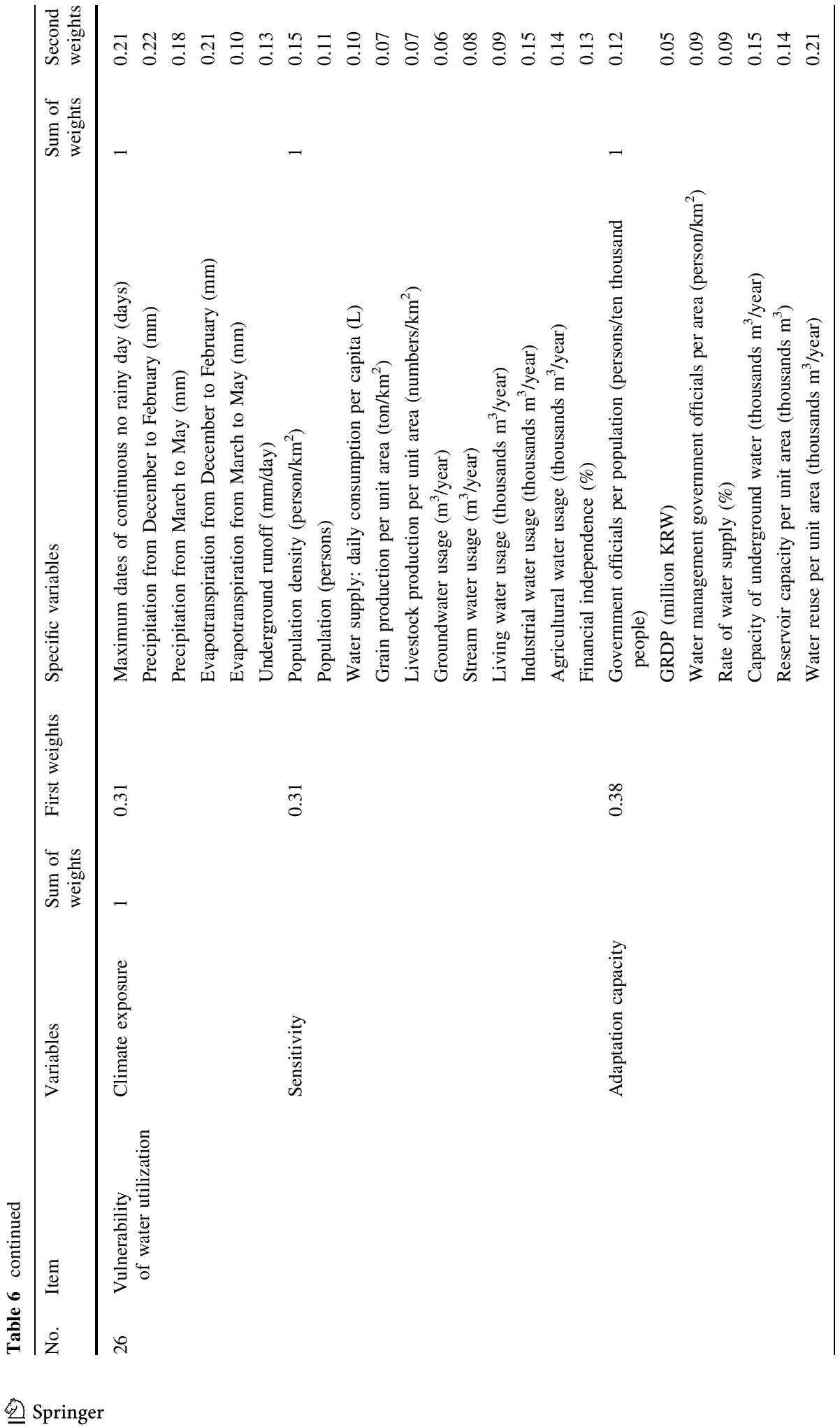




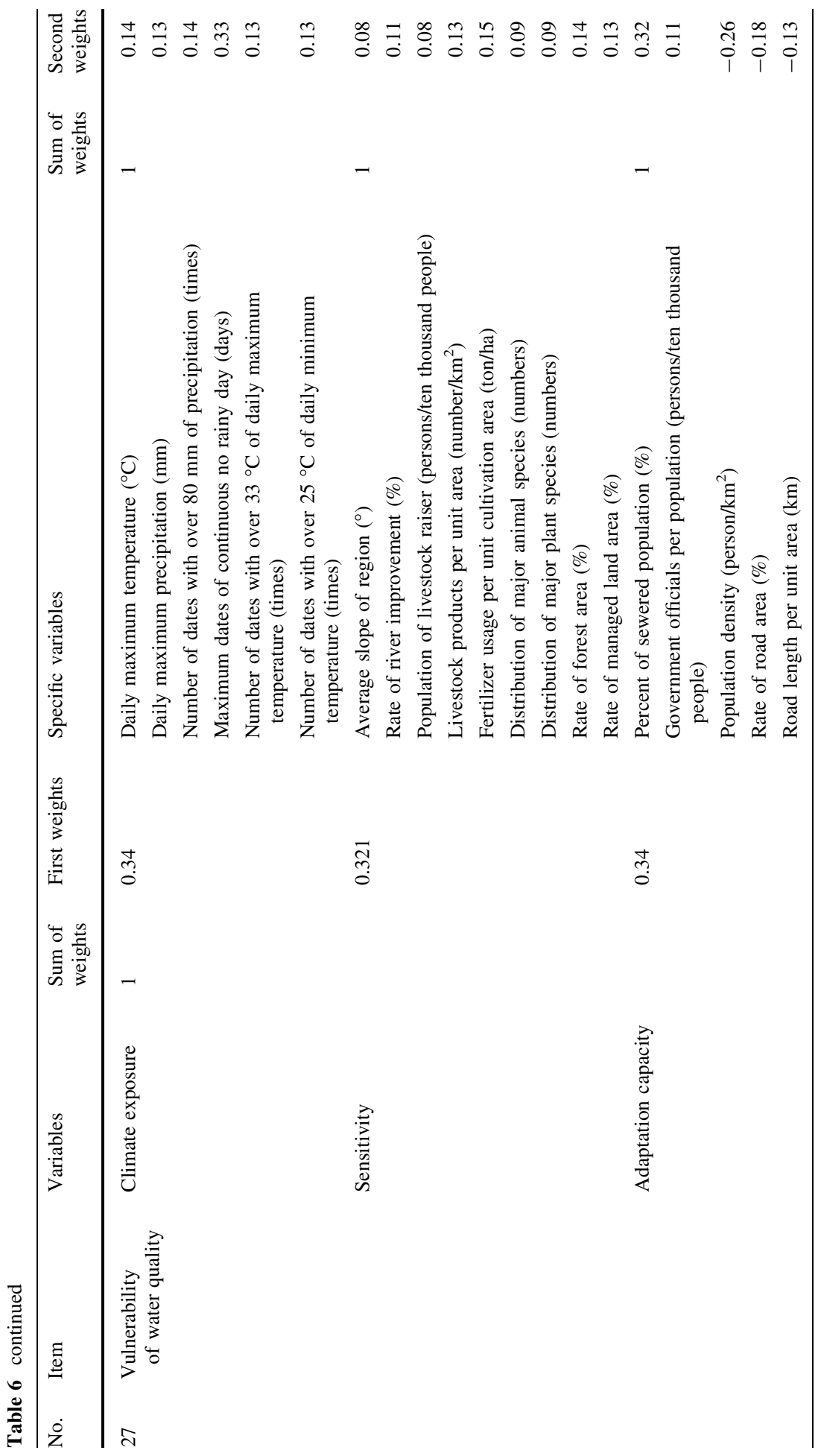




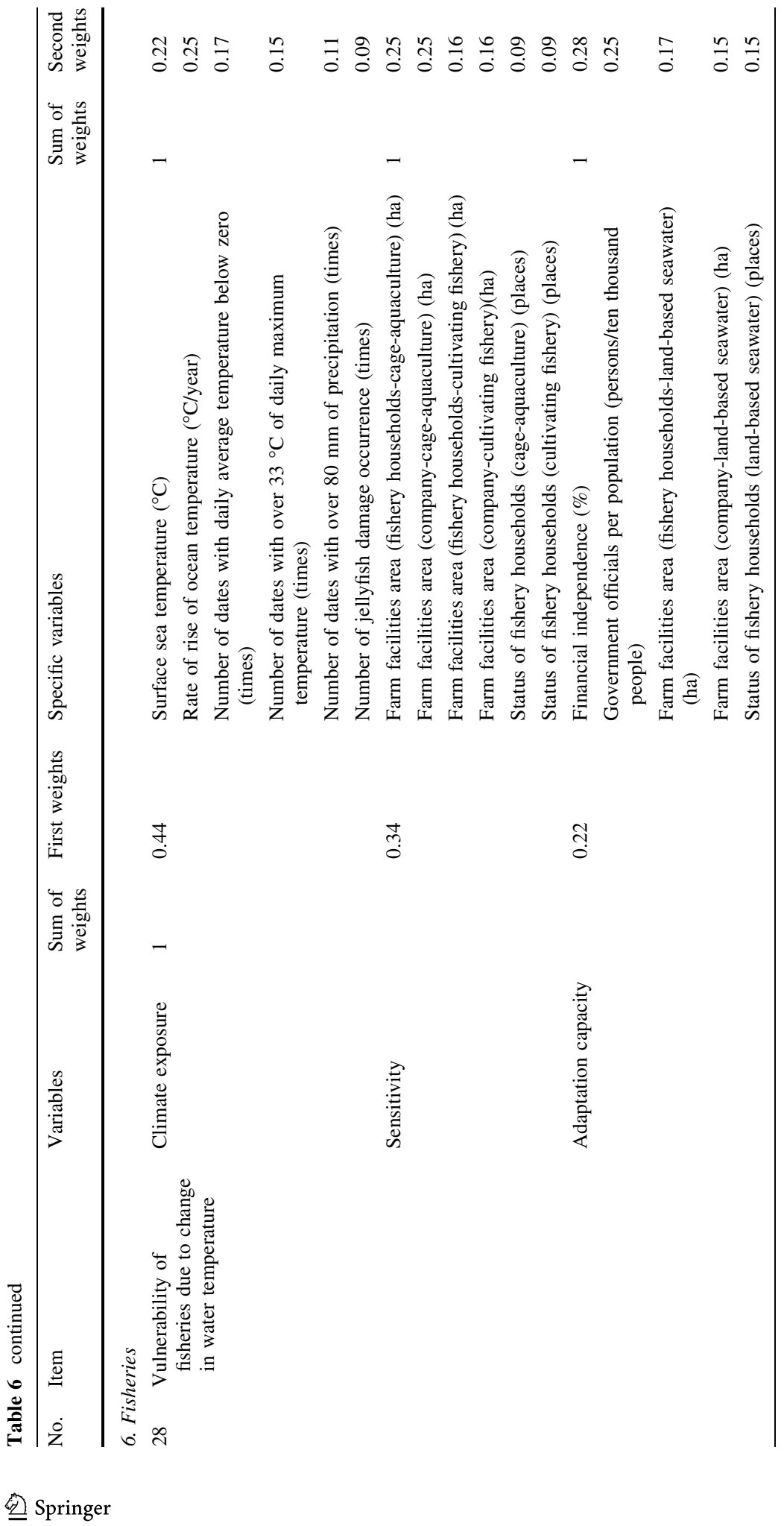




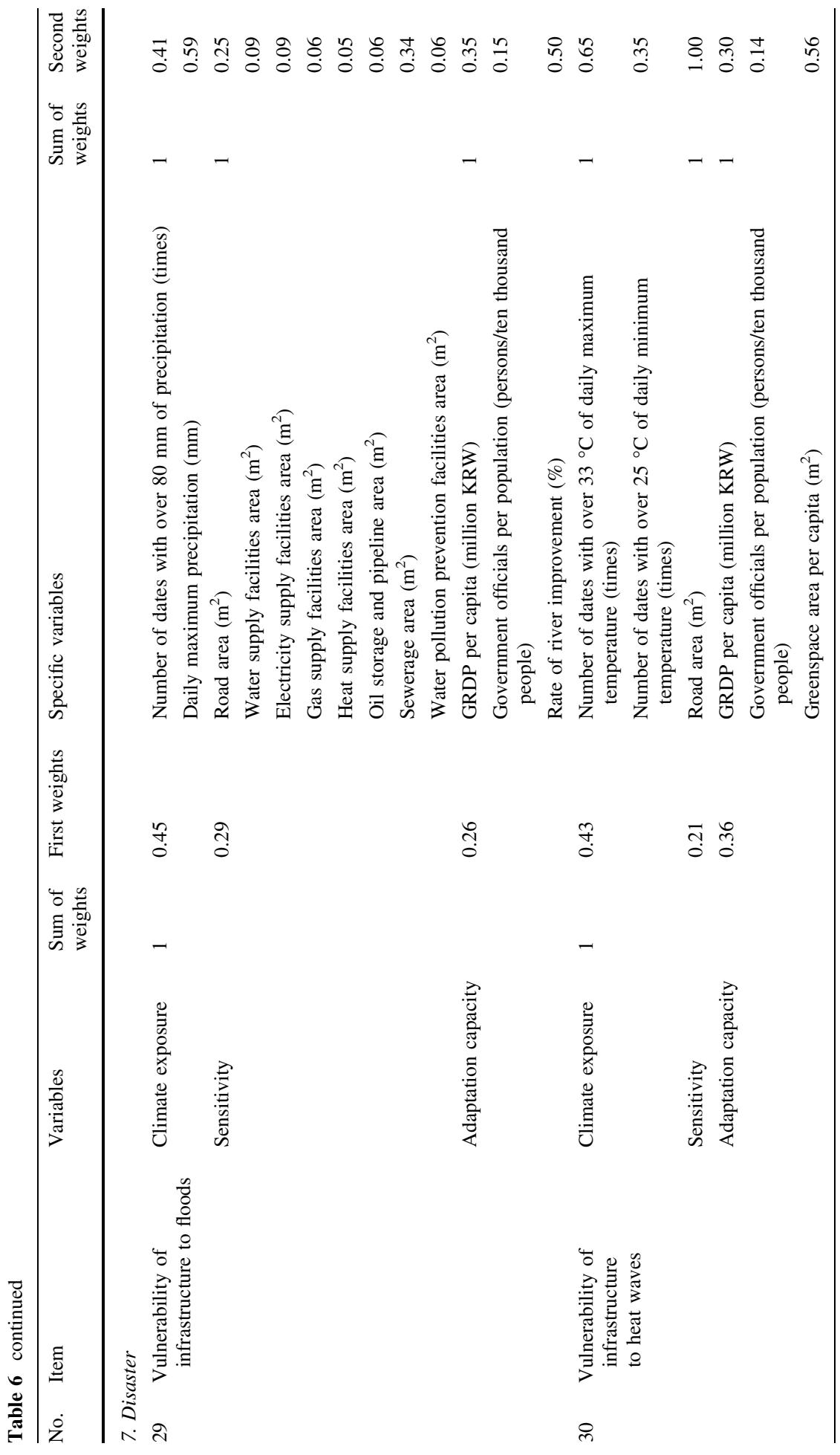




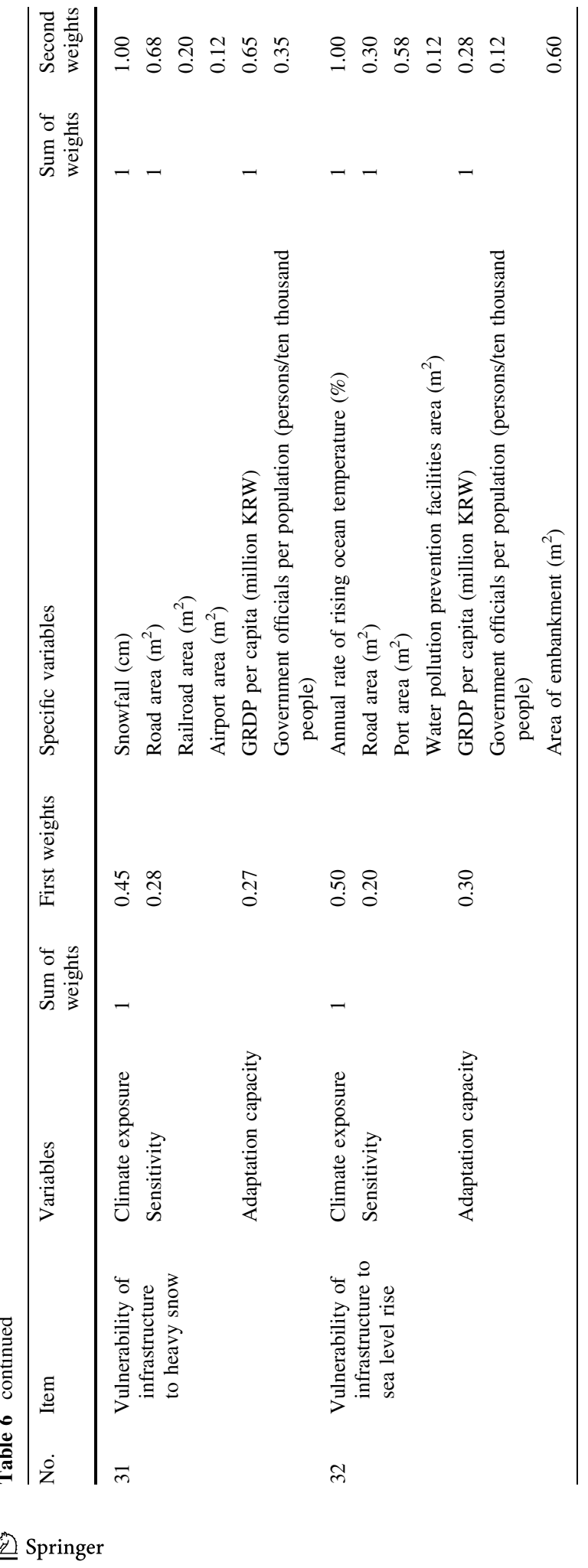




\section{References}

Adger WN, Vincent K (2005) Uncertainty in adaptive capacity. C R Geosci 337:399-410

Al-Adamat RAN, Foster IDL, Baban SMJ (2003) Groundwater vulnerability and risk mapping for the Basaltic aquifer of the Azraq basin of Jordan using GIS, Remote sensing and DRASTIC. Appl Geogr 23:303-324

Allison EH, Perry AL, Badjeck M-C et al (2009) Vulnerability of national economies to the impacts of climate change on fisheries. Fish Fish 10:173-196

Antwi-Agyei P, Fraser EDG, Dougill AJ et al (2012) Mapping the vulnerability of crop production to drought in Ghana using rainfall, yield and socioeconomic data. Appl Geogr 32:324-334

Arnell N, Tompkins E, Adger N, Delaney K (2005) Vulnerability to abrupt climate change in Europe, Technical Report 34, Tyndall Centre for Climate Change Research

Bonachea J, Bruschi VM, Hurtado MA et al (2010) Natural and human forcing in recent geomorphic change; case studies in the Rio de la Plata basin. Sci Total Environ 408:2674-2695

Bruschi VM, Bonachea J, Remondo J et al (2013) Land management versus natural factors in land instability: some examples in northern Spain. Environ Manage 52:398-416

Camarasa Belmonte AM, López-García MJ, Soriano-García J (2011) Mapping temporally-variable exposure to flooding in small Mediterranean basins using land-use indicators. Appl Geogr 31:136-145

Eckert S, Jelinek R, Zeug G, Krausmann E (2012) Remote sensing-based assessment of tsunami vulnerability and risk in Alexandria, Egypt. Appl Geogr 32:714-723

European Environment Agency (2012) Climate change, impacts and vulnerability in Europe 2012, EEA Report No 12

Fekete A (2012) Spatial disaster vulnerability and risk assessments: challenges in their quality and acceptance. Nat Hazards 61:1161-1178

Frazier TG, Thompson CM, Dezzani RJ (2014) A framework for the development of the SERV model: a spatially explicit resilience-vulnerability model. Appl Geogr 51:158-172

Füssel H-M, Klein RJT (2006) Climate change vulnerability assessments: an evolution of conceptual thinking. Clim Change 75:301-329

Houghton A, Prudent N, Scott JE III et al (2012) Climate change-related vulnerabilities and local environmental public health tracking through GEMSS: a web-based visualization tool. Appl Geogr $33: 36-44$

IPCC (2012) Managing the risks of extreme events and disasters to advance climate change adaptation. A special report of working groups $\mathrm{i}$ and ii of the intergovernmental panel on climate change. Cambridge University Press

Jeffers JM (2013) Integrating vulnerability analysis and risk assessment in flood loss mitigation: an evaluation of barriers and challenges based on evidence from Ireland. Appl Geogr 37:44-51

Kil S-H, Lee DK, Kim HG et al (2015) Comparing potential unstable sites and stable sites on revegetated cut-slopes of mountainous Terrain in Korea. Sustainability 7:15319-15341

Kim HG, Lee DK, Park C et al (2015) Evaluating landslide hazards using RCP 4.5 and 8.5 scenarios. Environ Earth Sci 73:1385-1400

Kim Y, Seo C, Ryu J et al (2013) Vulnerability assessment on the location of industrial complex considering climate change-focusing on physical and economic features of province industrial complex. Korean Soc Environ Impact Assess 22:627-637

Lee Y, Kim S, Park K (2007) Prediction of future land use using times series landsat images based on CA (cellular automata)-Markov technique. The Korean Society of Remote Sensing, Seoul, pp 55-60

Lee D, Park C, Tomlin D (2013) Effects of land-use-change scenarios on terrestrial carbon stocks in South Korea. Landsc Ecol Eng 1-13. doi:10.1007/s11355-013-0235-6

McGillivray M, White H (1993) Measuring development? The UNDP's human development index. J Int Dev 5:183-192

Menoni S, Molinari D, Parker D et al (2012) Assessing multifaceted vulnerability and resilience in order to design risk-mitigation strategies. Nat Hazards 64:2057-2082

Mikami T, Shibayama T, Esteban M et al (2014) Tsunami vulnerability evaluation in the Mentawai islands based on the field survey of the 2010 tsunami. Nat Hazards 71:851-870

Moreno A, Becken S (2009) A climate change vulnerability assessment methodology for coastal tourism. J Sustain Tour 17:473-488

Noorbakhsh F (1998) The human development index: some technical issues and alternative indices. J Int Dev 10:589-605

o'Brien K, Leichenko R, Kelkar U et al (2004) Mapping vulnerability to multiple stressors: climate change and globalization in India. Glob Environ Change 14:303-313 
Park J, Lee Y, Kim S, Lee M (2007) The effect of future land use change on hydrology and water quality using SWAT model. Korea Spatial Information Society, Seoul, pp 117-123

Ryu J, Han M, Hwang H et al (2014) Evaluation and application of CLUE-S model for spatio-temporal analysis of future land use change in total water pollution load management system. Korean Soc Water Envrion 30:418-428

Schneider SH, Semenov S, Patwardhan A et al (2007) Assessing key vulnerabilities and the risk from climate change. Contribution of working group II to the fourth assessment report of the intergovernmental panel on climate change. Cambridge, UK

Siagian TH, Purhadi P, Suhartono S, Ritonga H (2014) Social vulnerability to natural hazards in Indonesia: driving factors and policy implications. Nat Hazards 70:1603-1617

Silva M, Pereira S (2014) Assessment of physical vulnerability and potential losses of buildings due to shallow slides. Nat Hazards 72:1029-1050

Sullivan CA, Meigh J (2007) Integration of the biophysical and social sciences using an indicator approach: addressing water problems at different scales. Integr Assess Water Resour Glob Change, 111-128

Tran LT, O'Neill RV, Smith ER (2010) Spatial pattern of environmental vulnerability in the Mid-Atlantic region, USA. Appl Geogr 30:191-202

Turner BL, Kasperson RE, Matson PA et al (2003) A framework for vulnerability analysis in sustainability science. Proc Natl Acad Sci 100:8074-8079

Varazanashvili O, Tsereteli N, Amiranashvili A et al (2012) Vulnerability, hazards and multiple risk assessment for Georgia. Nat Hazards 64:2021-2056

Wang HB, Wu SR, Shi JS, Li B (2013) Qualitative hazard and risk assessment of landslides: a practical framework for a case study in China. Nat Hazards 69:1281-1294

White KS, Ahmad QK, Anisimov O et al (2001) Climate change 2001: impacts, adaptation and vulnerability. Contribution of working group II to the third assessment report of the intergovernmental panel on climate change 